\title{
The Horwitz Thesis and the History of Contracts
}

\section{A. W. B. Simpsont}

In his article, The Historical Foundations of Modern Contract Law, ${ }^{1}$ subsequently republished and enlarged as a chapter in The Transformation of American Law 1780-1860, ${ }^{2}$ Professor Morton J. Horwitz advanced a striking new interpretation of the evolution of American and English contract law in the late eighteenth and nineteenth centuries. This interpretation is related to his general thesis about the "transformation" of American private law in the period covered by the book. Horwitz claims that the private law of the eighteenth century was benign, reflecting the assumptions of a "premarket economy," ${ }^{3}$ and that its function was to impose a natural and objectively just order upon society. By a variety of mechanisms the law was then adapted to legitimate and facilitate the inequalities of the nineteenth-century market economy in which entrepreneurs flourished and the weak suffered.

I do not propose in this article to consider Horwitz's general thesis, but rather its particular application to certain aspects of contract law. Horwitz argues that there occurred a radical shift in

$\dagger$ Professor of Law, University of Kent at Canterbury and Visiting Professor of Law, The University of Chicago, Spring, 1979. I should like to acknowledge the great assistance which I have had in preparing this article from Professor John H. Langbein and Emile Karafiol.

' Horwitz, The Historical Foundations of Modern Contract Law, 87 HaRv. L. Rev. 917 (1974).

2 The article appears as Chapter VI, "The Triumph of Contract," in M. HoRwrtz, ThE Transpormation OP AMzRICAN LAw 161-210 (1977), with a paragraph, id. at 166 (lines 3-18), and a long passage on "Custom and Contract," id. at 188-210, added. This article will not discuss these additions.

${ }^{3}$ Horwitz, supra note 1, at 930. See text and notes at notes 31-36 infra. 
contractual theory in the late eighteenth and early nineteenth centuries. Before the change, the justification of contractual obligation was sought in "the inherent justice or fairness of an exchange."4 Eighteenth-century courts, concerned with justice, "limited and sometimes denied contractual obligation" when the underlying exchange was unfair..$^{5}$ They assumed that things had their proper price: price, or value, did not depend solely on the operation of market forces. ${ }^{6}$ This general philosophy found expression in what Horwitz calls the "equitable conception of contract."7 The eighteenth century also held to what Horwitz calls the "title theory of exchange"-it understood contract primarily as a mechanism for transferring property and not as a mechanism for securing expectations. ${ }^{8}$

Then, beginning in the last quarter of the eighteenth century, the equitable approach to contract was replaced by the notion that the source of contractual obligation was not the justice of the bargain but the convergence of the wills of the contracting parties. ${ }^{9}$ Horwitz elaborately develops a pessimistic interpretation of the cases, presenting what might be regarded as minor changes in the somewhat technical doctrines of contract law as fitting neatly into a process that converted a more humane body of law into a weapon of oppression. Once devised, the new scheme of contract law was reinforced by that most ill-defined of legal ailments, formalism, ${ }^{10}$ which supposedly arose after 1825 or 1830 , gathered momentum in the 1840's and developed strongly after $1850 . .^{11}$

Underlying Horwitz's argument is a romanticized view of English law before the "transformation" and, indeed, before the eighteenth century. But the heart of his argument lies in his view that eighteenth-century contract law reflected an equitable conception or theory of contract, which was "essentially antagonistic to the interests of commercial classes,"12 and that this conception was replaced by an approach more congenial to the needs of a commercial, market economy. As Horwitz presents it, this argument is hard to

+ Horwitz, supra note 1 , at 917.

s Id. at 923.

- Id. at 926-27.

IId. at 919 .

s Id. at 920-21, 923. Horwitz does not discuss in detail the doctrine that a contract for the sale of specific goods passes property to the buyer before delivery, a doctrine which of course survives.

- Id. at 917-18.

10 M. Horwirz, supra note 2, at 201, 253-66.

"See id. at 254, 256, 258-59.

12 Horwitz, supra note 1, at 927. 
test against the evidence-partly because it is so general and partly because Horwitz, with true rhetorical mastery, interweaves evidence from England and America, from different periods of time, and from different types of cases. His argument does, however, rest upon a number of specific propositions that can be related to evidence. ${ }^{13}$ In his view, eighteenth-century courts (1) did not fully recognize the executory contract; ${ }^{14}$ (2) did not award expectation damages; ${ }^{15}$ (3) accepted inadequacy of consideration as a well established ground for refusing a decree of specific performance; ${ }^{16}$ (4) accepted a "substantive doctrine of consideration" whereby juries in contract cases were to reduce damages where consideration was inadequate $;^{7}(5)$ implied a warranty of quality where the price was at least the normal price charged for the goods; ${ }^{18}$ and (6) allowed the joining of counts in express and implied contract. ${ }^{19}$ Horwitz argues that each of these positions was abandoned in the late eighteenth and early nineteenth centuries.

I will address the general issue of Horwitz's view of pre"transformation" English law in the first part of this article. In the second and major section of the article, I will try to demonstrate, by a detailed investigation of Horwitz's sources, that the evidence he adduces for the specific propositions underlying his thesis is very weak. Horwitz also supports his argument by analyzing treatises on contracts published in the late eighteenth and early nineteenth centuries. The third part of the article will consider that body of evidence. I will conclude with some suggestions regarding the general interpretation of the evolution of contract law in this period.

\section{The Good Old LaW}

Horwitz supports his thesis that, starting in the late eighteenth century, the law of contract was transformed into an instrument of class oppression, with a romanticized view of earlier English law and society. This support is not logically necessary to his thesis. A Marxist might have argued that the English commercial bourgeoisie,

${ }_{13}$ This list is not exhaustive, but it contains the most important propositions into which Horwitz's thesis about the equitable conception of contract can be analyzed.

" Horwitz, supra note 1, at 919-20, 929-31, 936. Horwitz does not state categorically that executory contracts were never recognized, but that they were rarely enforced, or that there were no rules to cope with them. He does state that in some jurisdictions in the eighteenth century executory contracts were not enforced without part performance. See id. at 929-30.

is Id. at 936-37.

16 Id. at 923-24.

17 Id. at 924.

1x Id. at 926-27.

"Id. at 934-35. 
linked with elements in the landed classes, forged an equitable theory of contract in the eighteenth century as a weapon in their struggle with a law reflecting earlier, less commercial times; and that once it triumphed, the new order cut back on the dangerous legal doctrines it had used against the old. But this is emphatically not Horwitz's position. His view of the history of English and American law appears to be linear, not dialectical. He presents the benign and equitable elements in eighteenth-century contractual theory not as innovations associated with the growth of commercial (preindustrial) capitalism, but as the approach to contract that is appropriate to a precommercial society.

Horwitz suggests in various ways that eighteenth-century English law and society were closer to a simple and morally pure earlier state than to the rapacious world of the nineteenth century. One problem with these suggestions is that the image projected of that earlier state is often skewed. For example, by using expressions like "the medieval tradition of substantive justice,"20 "theories of objective value and just price," "this remnant of the medieval just price theory of value," 22 Horwitz relates his eighteenth-century equitable theory of contract to medieval and presumably postmedieval doctrines associated with notions of just price. Unfortunately, Horwitz tends here to perpetuate a myth that scholars have long attempted to put to rest. ${ }^{23}$ His rather vague references should be received with some caution if they are intended to suggest that there was a single doctrine that was generally accepted by medieval or postmedieval secular tribunals dealing with contract law, and that this doctrine was hostile to competitive markets.

The idea of a just price goes back in Christian thought at least to St. Augustine of Hippo. ${ }^{24}$ From Aquinas onward, the Christian moralists, responding to the rapid growth of commerce in the high Middle Ages, argued in favor of high ethical standards in bargain-

Id. at 917 .

21 Id. at 946.

22 Id. at 935. See also id. at 946 n.153.

2s See generally 1 W. Ashley, Economic History and Theory 132-48 (1931); G. O'Brien, An Essay on Mediaeval Economic Teaching 102-36 (1920); The Just Price (V. Demant ed. 1930); de Roover, The Concept of the Just Price: Theory and Economic Policy, 18 J. Econ. Hist. 418 (1958). See also de Roover, Monopoly Theory Prior to Adam Smith: A Revision, 65 Q.J.'Econ. 492 (1951), reprinted in R. DE Roover, Business, BANKING AND Economic Thought in Late Medieval and Earty Modern Europe 273, 277-78, 290 (J. Kirshner ed. 1974). For an appraisal of de Roover's views on scholastic price theory, see Kirshner, Raymond de Roover on Scholastic Economic Thought, in id. at 15, 22-26.

24 St. Augustine used the expression justum pretium in DE TrINITATE XIII. 3 . It is also found in the Corpus IurIs, COD. 4, 44, 2, but its meaning there is problematic. 
ing. ${ }^{25}$ They rejected as sinful all forms of fraud, trickery, and evasion, and all exploitation of the particular weakness of individuals. With this approach, they developed and elaborated notions of the just price of commodities at which commerce could take place without $\sin$. The prevailing view came to be that the just price is fixed by common estimation (communis aestimatio) in a fairly conducted market-in the absence of fraud, monopoly, or coercion; value as set by the community was contrasted with special value to the individual. ${ }^{26}$ The monopolist, not the market, was seen as the great enemy of the just price. Consequently, in the absence of a fairly conducted market, or when unusually poor conditions of supply or unusually heavy demand threatened to imbalance the market, the just price was to be imposed by legal regulation. It was common enough for prices to be determined that way in medieval and early modern times, but given normal conditions, the fair or just price was the market price, or the price set by ordinary supply and demand.

The civilians, in contrast, based themselves primarily on texts in the Digest and in particular on opinions of Paul, Ulpian, and Pomponius, which did not speak of just price, but recognized that contracting parties could lawfully outwit each other over the price. ${ }^{27}$ A limited exception to this principle, derived from rescripts of the emperors Diocletian and Maximinian in the Codex, ${ }^{28}$ allowed a sale to be set aside if the price was less than half a true (verum) or proper (iustum) price. This rule of laesio enormis, formulated in a variety of ways by different authors, ${ }^{29}$ came generally to be restricted to

${ }^{25}$ See generally $1 \mathrm{~W}$. AsHLEY, supra note 23, at 132-48; R. DE ROover, supra note 23, at 277 n.1 (correcting Ashley).

26 It was in this sense that the just price was "objective." It was conceded that there was a degree of latitude in the just price: Aquinas put it that "the just price of things is not fixed with mathematical precision, but depends on a kind of estimate, so that a slight addition or subtraction would not seem to destroy the equality of justice." T. Aquinas, Summa Theologica pt. 2, Q. 77, art. 1, at 320 (Fathers of the English Dominican Province trans. 1929). See note 23 supra, especially the works of de Roover and Kirshner cited therein.

When discussing the "market price," one needs to bear in mind that strictly speaking there is a distinction between the modern economist's abstract sense of "the market" and the older, more literal sense of a place where buying and selling regularly and lawfully goes on. In the older sense there is, for example, no market price for land; land is not sold in the market. But although there is no "market" for rooms in an inn, the just price for such a room need not be imposed by regulation. It is the price charged ordinarily, absent sudden surges in demand such as would occur with the unexpected arrival of a group of pilgrims.

${ }^{27}$ Digest 4.4.16.4, 19.2.22.3. These texts need to be read in the context of the Roman rules regarding defects of quality and the general obligation to act with good faith.

${ }^{28}$ CoD. 4, 44, 2 and 4, 44, 8 (Rescript of 285 A.D.). Some scholars have suspected that the language in question was interpolated by the compilers.

20 Domat, for example, states the position as follows:

There are some commodities, of which the price may be regulated for the public good; 


\section{sales of immovables.}

The extent to which secular courts in medieval or postmedieval Europe acted upon the views of either the theologians or the civilians raises complex questions on which I am not competent to pronounce. In English common law there is, so far as I am aware, no evidence for the general reception of either. ${ }^{30}$ The point I wish to stress here is that neither civilians nor Christian moralists, both trying to adapt received notions to the needs of a society with growing commercial activity, were hostile in principle to a functioning market as a price-setter.

Throughout his analysis, Horwitz implies that eighteenthcentury contract law reflected the values of a society whose economy was not only preindustrial in the sense that it had not yet been transformed by the "industrial revolution," but one that was simple, agrarian, and in some sense "pre-market,"31 and which therefore bred values that were "pre-commercial,"32 or at least "antagonistic to the interests of commercial classes." 33 While Horwitz applies these terms to America more than to England, ${ }^{34}$ and his sparse evidence comes from America as much as from England, ${ }^{35}$ it is in

as it is, for example, in bread, and other things, in some countries. But setting aside these regulations, the price of things is undetermined. And since it ought to be differently regulated according to the different qualities of the things, and according to the plenty and scarcity both of money and of the commodities, the easiness or difficulty of the carriage, and other causes which increase or diminish the value; this uncertainty of price makes an extent of more and of less, which requires that the seller and buyer should adjust between themselves the price of the sale.

1 J. Domat, The Civil Law in Its Natural Order 217 (3d ed. W. Strahan trans. Boston 1850) (1st ed. London 1722) (translation of LES LOIS CIVILES DANS LEUR ORDRE NATUREL (Paris 1694)). Domat also states the doctrine of laesio enormis in the case of immovables. Id. at 228.

${ }^{30}$ With respect to equity, see text and notes at notes 151-187 infra; for the common law, see text and notes at notes $44-47$ infra.

${ }^{31}$ Horwitz, supra note 1 , at 930 . The term is here applied to the economy of colonial America, but Horwitz makes the same point more emphatically for England in the introduction to his article, where he states that "Powell's argument [as proposed in 1790] against conceptions of intrinsic value and just price reflects major changes in thought associated with the emergence of a market economy." Id. at 918. In other words, until the second half of the eighteenth century, England did not enjoy (or suffer from) a "market economy." Horwitz follows the sentence just quoted with another that appears to support it, but in fact states a much more limited, and much less relevant claim: "It appears that it was only during the second half of the eighteenth century that national commodities markets began to develop in England." Id. (emphasis added). See text at notes 39-40 infra.

${ }_{32} \mathrm{M}$. HoRwITz, supra note 2, at 211 (referring to "a still dominant precommercial consciousness of rural and religious America").

${ }^{33}$ Horwitz, supra note 1, at 927 (referring to both England and America).

is See notes 31-33 supra.

35 For example, Horwitz supports the statement quoted in note 31 supra, about the late emergence of a "market economy," with the point that "[i]n America, widespread markets in government securities arose shortly after the Revolutionary War." Horwitz, supra note 1 , 
England that the Chancellor and courts supposedly developed the equitable conception of contract. Thus, if the image of economic backwardness he presents is relevant to eighteenth-century AngloAmerican contract law, it must be applicable to eighteenth-century English society.

Although there is room for judgment here, the suggestion that English law reflected a relatively simple and primitive ${ }^{36}$ economy is odd in a work dealing with the law as it was pronounced by the King's Chancellor and the King's courts in London, not as it was spoken in small borough courts and village tribunals. England, even in the first half of the eighteenth century, was the greatest trading nation in the world, and its trade was supported by a sophisticated mercantile community well versed in techniques of shipping, financing, and insuring cargoes around the world. ${ }^{37}$ Equally important, England was second to none in the skill and depth of its commercial and industrial infrastructure. Horwitz emphasizes that a national commodities market grew up in England only in the second half of the eighteenth century. ${ }^{38}$ This is debatable, ${ }^{39}$ and not very relevant. Important regional markets affected a large part of the population no later than the beginning of the century; ${ }^{40}$ just feeding and supplying London oriented much of the

at 918 . He says nothing about England's securities markets here, but at his cross-reference at 937, he points out that "Lord Mansfield in 1770 referred to a speculative interest in stock as 'a new species of property, arisen within a compass of a few years.' "Id. at 937 (quoting Nightingal v. Devisme, 5 Burr. 2589, 2592, 98 Eng. Rep. 361, 363 (K.B. 1770)). Whatever Lord Mansfield may have been referring to, speculation in paper was common in England in the first half of the eighteenth century, when the equitable conception of contract was supposedly ascendant and not seriously challenged. The celebrated affair of the South Sea Bubble (1720) arose out of a national orgy of such speculation.

36 The word "primitive" may be thought too strong, but it is difficult to know how else to characterize an economy in which, according to Horwitz, goods were not yet "thought of as fungible," Horwitz, supra note 1, at 918.

37 See generally T. Ashton, An Economic History of England: The 18th Censtury (1955). On the sophisticated character of England's economy even before the eighteenth century, see J. Chartres, Internal Trade in England 1500-1700 (1977); Deane, The Industrial Revolution in Great Britain, in 4 The Fontana Economic History of Europe (The Emergence of Industrial Societies (pt. 1)) 161, 172-74 (C. Cipolla ed. 1973).

2* Horwitz, supra note 1 , at 918 . See note 31 supra.

39 See Granger \& Elliott, A Fresh Look at Wheat Prices and Markets in the Eighteenth Century, 20 Econ. Hist. Rev. (2d ser.) 256 (1967); 1 E. HobsBawm, Industry and Empire. The Making of Modern English Society, 1750 to tHe Present Day 24 (1968) (England in the eighteenth century before the industrial revolution "was not merely a market economy-i.e., one in which the bulk of goods and services outside the family are bought and sold-but in many respects it formed a single national market.").

to Horwitz's claim that until the development of a national commodities market the price of grain was "local," not "regional," Horwitz, supra note 1, at 918 (quoting K. PolanY, ThE Great Transformation: The Political and Economic Origins of Our Ttme 115 (Beacon Press 
country towards producing for a market. This is not to deny that there were regions, and sections of the population, relatively distant from the world of finance, commerce, and industry. But Horwitz's apparent premise that there must be a national market embracing almost everyone in society before the groups that shape the law can be influenced profoundly by commercial interests and needs is unsupportable. Again, I would not deny that the English aristocracy and gentry sometimes affected to despise commercial values in the eighteenth century (though perhaps no more than in the nineteenth). But to suggest that the law pronounced in Chancery and the common-law courts could ignore the needs of the commercial classes and their powerful allies in Parliament and the court reveals a profound misunderstanding of English politics and society in the eighteenth century and, for that matter, in the seventeenth as well.

These examples can be multiplied. In the second section of this article I will point out that Horwitz sometimes appears to misstate earlier English law in his attempt to show that it was only in the late eighteenth century that the courts and the treatise writers began to transform this law to meet what he conceives to be the needs of a commercial society. I want to close the present section, however, with a more general point. If the eighteenth-century law, in sharp contrast to what was to succeed it, was anticommercial and reflected, as Horwitz puts it, "the medieval tradition of substantive justice," ${ }^{41}$ we might expect that the pre-eighteenth-century common law of contract, and particularly the medieval law, would be even more benign and protective. Yet it is quite clear that this was not the case.

The typical medieval contract was the formal contract, the penal bond under seal; the harsh medieval law of the penal bond was notoriously based on the philosophy that those who made beds should lie in them. ${ }^{42}$ The law emphatically favored creditors over debtors, and despite the received objections to usury, the law rigorously enforced the recovery of penalties. ${ }^{43}$ So far as informal contracts are concerned (the point is palpable for contracts under seal),

ed. 1957)), is misleading if it is meant to imply-as it apparently does-that there were no regional markets in England until the second half of the eighteenth century. See Granger \& Elliott, supra note 39.

"Horwitz, supra note 1, at 917.

12 On the earlier law of contract, see generally A. Simpson, A History of the Common LAW OF Contract 88-126 (1975) (substantially incorporating Simpson, The Penal Bond with Conditional Defeasance, 82 L.Q. REv. 392 (1966)).

${ }^{13}$ A. Simpson, supra note 42 , at 113-15. 
there is not to be found a single hint in the case law of the fifteenth, sixteenth, or seventeenth centuries of the acceptance of a doctrine of just price. ${ }^{44}$ Scholars may attempt to explain away Chandelor $v$. Lopus $^{45}$ (1603), but it is more important to notice the complete absence of any suggestions in the case law of implied warranties of quality between 1603 and the late eighteenth century, with the possible exception of contracts for victuals ${ }^{48}$ and the very scanty evidence of a different attitude in late medieval common law. ${ }^{47}$

Throughout this period, and long after, imprisonment without term was the fate of the debtor who failed to deliver. ${ }^{48}$ As Edmund Plowden put it in 1551, with a certain lack of charm:

For if one be in Execution he ought to live of his own, and neither the Plaintiff nor the Sheriff is bound to give him Meat or Drink, no more than if one distrains Cattle, and puts them in a Pound .... [A]nd if he has no Goods, he shall live of the Charity of others, and if others will give him nothing, let him die in the Name of God, if he will, and impute the Cause of it to his own Fault, for his Presumption and ill Behaviour brought him to that Imprisonment. ${ }^{49}$

So spoke the greatest common lawyer of the time, a devout adherent of the old religion and a man who was offered the office of Chancellor by Elizabeth I. It is true that Chancery did, to a considerable extent, soften the extreme rigors of the common law's enthusiasm for creditors' rights-for example, by relieving against penalties, though this jurisdiction was established only in the seventeenth century. If, instead of selecting a short period of the eighteenth century for comparison with the nineteenth, one takes in the medieval common law as a basis for comparison, the picture of a loss of primeval innocence appears most implausible.

Horwitz's thesis does not stand or fall on this issue, of course. Whether he is right in his views about earlier English law, the char-

"Id., at 445-52. Horwitz, supra note 1, at 948-49, juxtaposes two passages from G. VerplancK, AN Essay on the Doctrine of Contracts 96, 104 (New York 1825), critical of justprice doctrine, as if they were directed at the received wisdom in the common-law world. They were not. The first comes from a chapter dealing only with "[t]he doctrines of the CrviL LAw, and of the modern systems founded on it," id. at 59 , while the second refers specifically to the "doctrines" of the "Civil Code" of Rome, id. at 103-04.

${ }^{13}$ Cro. Jac. 4, 79 Eng. Rep. 3 (Exch. Ch. 1603), noted in 8 Harv. L. Rev. 282 (1894), discussed in A. Simpson, supra note 42, at 412 n.1, 536 \& n.2.

"A. Simpson, supra note 42, at 536-37. See 3 W. Blackstone, Commentaries *165.

17 A. Simpson, supra note 42 , at $240-47$.

1* Id. at 587-93.

1 Dive v. Maningham, 1 Plowd. 60, 68 (C.P. 1550), reprinted with slight variations in 75 Eng. Rep. 96, 108-09. 
acter of English society before and during the eighteenth century, or the incompatibility of equitable doctrines of contract with the needs of entrepreneurs in an industrial society is ultimately of secondary importance. I will now turn, therefore, to a consideration of the evidence for his view that contract law was fundamentally different in the eighteenth century from what it became in the nineteenth because the eighteenth century accepted an equitable conception of contract that conceived of contract in terms of a "title theory of exchange" and looked to the fairness of an exchange before it would enforce its terms.

\section{The Equitable Conception of Contract}

Horwitz's thesis about the transformation of English and American contract law in the period $1780-1860^{50}$ rests essentially on his interpretation of eighteenth-century English contract law before the transformation. It is my view that the differences Horwitz claims to have discovered between eighteenth-century and early nineteenthcentury contract law are, for the most part, illusory. I am not saying that the law did not change in this period, but that the changes he describes were not the changes that occurred. In particular, many of the doctrines that he identifies as characteristic of the transformation were common in the eighteenth century.

I realize that any major change in the law does not happen overnight. It would not be very significant to find occasional cases in the eighteenth century stating what allegedly became law only in the nineteenth. I have not, therefore, focused on cases that Horwitz ignores, though they are noted where necessary. Rather, the focus of the following analysis is the evidence that Horwitz himself adduces in support of his thesis. Again, to show that his interpretation of the evidence is occasionally at fault would not be very significant, since this would not affect his general thesis. My contention is that Horwitz allowed himself to be misled by his striking and seductive thesis into a general and systematic misinterpretation of the evidence, and that his thesis, once tested in detail, is quite misconceived. In order to make the case for this view it is essential, if at times tedious, to subject his arguments to very close inspection.

so The dates are from the title of his book. In the main, his discussion of contract locates the change in the period 1790-1844, the precise dates corresponding with the publication of Powell's and Story's treatises on contract law. 1 \& 2 J. POWELL, Essay UPON THE LAW OF Contracts and Agreements (Dublin 1790); W. Story, A Treatise on the Law op Contracts Not Under SeAl (Boston 1844). 
I can see no other way of testing the validity of a thesis that, if correct, is of great historical importance.

\section{A. The Recognition of Executory Contracts}

Horwitz writes that "contrary to the orthodox view, the process [whereby the executory exchange became enforceable] was not complete at the end of the sixteenth century . . . . [A]s late as the eighteenth century contract law was still dominated by a title theory of exchange." ${ }^{11}$ It is difficult to come to grips with this position. What does it mean to say that the process "was not complete"? No one has claimed that the executory contract played precisely the same role in the sixteenth century as in the eighteenth, or as in the twentieth. In that sense, no process of institutional development is complete until that institution is dead. Similarly, nobody has claimed that the conception of contract as a set of mutual promises drove all other conceptions of contract out of the field in the sixteenth century-it has not done so even today. The issue is, or should be, whether the exchange of promises was a recognized, standard way for parties to conclude a mutually enforceable agreement in the eighteenth century. That the place of executory contracts in early modern English law was different from what it is today does not mean that the law did not fully recognize such contracts. I have set out elsewhere a detailed explanation of the processes whereby socalled executory contracts came to be recognized and, perhaps more important, an analysis of what this expression means, ${ }^{52}$ but a short summary here may clarify what Horwitz has misunderstood.

It was settled in the sixteenth century that mutual promises could be consideration for each other..$^{53}$ In such a case, a plaintiff could sue for breach without averring performance, the other party being put to his counter-action. The doctrine originated with wagers, where it is logically necessary. ${ }^{54}$ Not all exchanges of promises, however, were analyzed as bilateral, executory contracts in the modern sense-as promise-for-promise cases. It might be the intention of the parties that the consideration should be the performance, not the promise. In such a case, the plaintiff had to show performance before he could sue: the promise itself was not actionable because if performance had not yet occurred, there was not yet considera-

\footnotetext{
s1 Horwitz, supra note 1, at 920.

52 A. Simpson, supra note 42, at 452-70. See generally id. at 406-88.

53 Id. at $459-70$.

st The first case is West v. Stowel, 2 Leo. 154, 74 Eng. Rep. 437 (C.P. 1577).
} 
tion. ${ }^{55}$ An alternative conceptual scheme for achieving the same practical result employed the concept of a condition: the defendant's promised performance might be conditional upon prior or simultaneous performance by the plaintiff, so that the plaintiff would lose unless he could show performance or tender. ${ }^{56}$

Very elaborate rules evolved for these situations. They offered a guide to whether the parties intended to treat a counter-promise or only its performance as consideration and, using the concept of conditional obligation, dealt with the mutual dependence or independence of promises. ${ }^{57}$ Their application caused endless difficulty. ${ }^{58}$ The existence of these rules does not mean, however, that contemporaries were "confused" about the nature of contract, and it does not contradict the proposition that the law recognized pure promise-for-promise contracts. Rather, these rules were an integral part of the promise-for-promise doctrine. One can understand what was meant by an executory contract in this period only by keeping in mind the existence of these rules, for they defined the limits of the pure promise-for-promise contract and set forth other ways in which a promise might become the source of a future binding obligation.

Finally, it must be noted that the voluminous case law on the subject, from the mid-sixteenth century until the nineteenth, is primarily concerned with establishing when a plaintiff can sue, rather than when a person may unilaterally withdraw from a promise before breach..$^{39}$ In the earliest cases in which the latter issue was aired, it was regarded-however surprising we may find this-as a

ss A. SimpSon, supra note 42 , at $459-70$.

ss Id. at 102.

${ }^{57}$ These rules are associated with the leading cases of Pordage v. Cole, $1 \mathrm{Wms}$. Saund. 319, 85 Eng. Rep. 449 (K.B. 1669), and Cutter v. Powell, 6 T.R. 320, 101 Eng. Rep. 573 (K.B. 1795).

58 For statements about the period of the "transformation," see J. ChITTY, A Practical Treatise on the Law of Contracts, Not Under Seal 273-74 (London 1826); 1 W. SelwyN, AN Abridgment of the LaW of Nisi Prius 102-09 (3d ed. London 1812) (1st ed. London 1806);

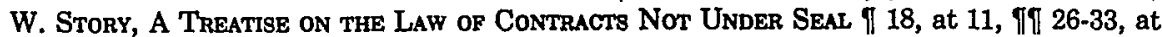
19-25 (2d ed. Boston 1847) (1st ed. Boston 1844). The rules tended to be regarded as pleading rules, rather than substantive principles of contract law. As Selwyn points out, "[t]he principal difficulty in the construction of agreements consists in discovering, whether the consideration be a condition precedent, a concurrent act, or a mutual promise." W. SELWYN, supra, at 109. The effect of these rules was that it was most unusual for a plaintiff to be able to sue for breach without showing performance or tender. But this is the situation today as well; it does not mean that the law of contract was abandoned the executory contract. The evidence is discussed in W. Nelson, Ambricanization of the Common LaW 56-59 (1975).

57 For the doctrine of "countermand," see A. Simpson, supra note 42, at 466-70. The notion seems to disappear silently. It revives in a new form with Cooke v. Oxley, 3 T.R. 653, 100 Eng. Rep. 785 (K.B. 1790). 
distinct issue. Eventually, by a process still not understood, it was settled that the giving of a consideration for a promise, whether that consideration was an act or a counter-promise, made the promise binding. When the doctrine of offer and acceptance entered in the nineteenth century, it expressed this view. ${ }^{60}$

In support of his thesis that the recognition of executory contracts came late, Horwitz develops an argument that involves a contrast between what he calls the "title theory of exchange" and the recognition of executory contracts. ${ }^{61}$ If I understand the argument, it is that under the former theory contracts are viewed primarily as a form of conveyance of property rather than as arrangements binding the parties to future performance. This conception certainly did exist, and it has a long history. ${ }^{62}$ It is still useful today to treat contracts as a type of conveyance; thus the sale of goods is still in English law said to pass "property" in certain circumstances to the buyer. ${ }^{63}$ Furthermore, in a more general sense a contractual right can be viewed as a form of property right being created by the contractual transaction.

Horwitz relies primarily on a reading of Blackstone to support his statement that the title theory dominated the eighteenthcentury view of contract and his implication that this excluded the alternative conception of contracts as arrangements binding the parties to future performance. He stresses that "[i]n Blackstone's Commentaries contract appears for the first time in Book II, which is devoted entirely to the law of property . . . and for the second and last time in a chapter entitled, 'Of Injuries to Personal Property." "B4 But Horwitz has exaggerated and misunderstood the significance of this arrangement.

The main problem faced by any treatise writer is organization, and once a scheme is presented in a successful work, others tend to follow it. In Matthew Hale's The Analysis of the Law, ${ }^{65}$ written in the seventeenth century but first published in 1713, contract law was somewhat unhappily accommodated twice: first in the basic category of "Rights" and second in the basic category of "Wrongs." 66

6o See generally Simpson, Innovation in Nineteenth Century Contract Law, 91 L.Q. REv. 247 (1975).

" See text at note 50 supra.

¿See A. Simpson, supra note 42 , at $\mathbf{1 8 5 - 9 3}$.

"See generally P. AtiYah, The Sale of Goods 141-45 (5th ed. 1975); 2 Chitty on ConTracts $\$ \S 4490-4510$ (A. Guest gen. ed. 24th ed. 1977).

" Horwitz, supra note 1, at 920 (footnote omitted).

"S M. Hale, The ANalysis of the Law (London 1713) (published posthumously).

"Id. at 79-80, 120-23. 
Blackstone, with only slight modifications, followed this arrangement. ${ }^{67}$ In relation to "Rights," contracts are a mode of transferring property, the right either to a thing in possession or to a thing in action-and that is how Blackstone treats contract in Book II. ${ }^{68}$ In relation to "Wrongs," a contract is viewed as an agreement for the future, and failure to perform is an actionable wrong-and that is how Blackstone treats it in the discussion of private wrongs to personal property in Book III. ${ }^{69}$ Blackstone, in short, deals with contract both ways, and he does so not because he is reflecting some prevailing theory of eighteenth-century law, but for the mundane reason that he is faithfully following Hale's scheme of organization, the best one he knew. It is a mistake to attach too much significance to the form in which Blackstone presents contract in Book II at the expense of neglecting the presentation in Book III. An understandable plagiarism, not high contractual theory, explains Blackstone's treatment of contract.

Horwitz also supports his thesis with the argument, limited to America, that American courts did not enforce executory contracts unless there had been at least part performance..$^{70}$ His somewhat sparse evidence for this statement is not convincing. The doctrine he reports ${ }^{71}$ from John Adams's Commonplace Book ${ }^{72}$ concerns promise-for-act agreements, in which performance was in standard doctrine a prerequisite of obligation. ${ }^{73}$ Orthodox law is also set out in Zephaniah Swift's A System of the Laws of the State of Connecticut. ${ }^{74}$ Swift, whom Horwitz portrays as wavering between recognition and nonrecognition of executory contracts, ${ }^{75}$ merely

${ }^{67}$ Similarly, Blackstone employs Hale's distinction between express and implicit contracts. Compare 3 W. Blackstone, Commentaries *153 with M. HaLE, supra note 65, at 121.

ax $2 \mathrm{~W}$. Blackstone, Commentaries *40-70.

69 3 id. at *153-66.

${ }^{70}$ Horwitz, supra note 1, at 929-31. Horwitz's third argument for his thesis regarding executory contracts, which links the recognition of such contracts with the award of expectation damages, see id. at 936 , will be discussed in the following section.

"Id. at 930 . See note 73 infra.

121 Legal Papers of John Adams 4 (L. Wroth \& H. Zobel eds. 1965).

73 The full text makes this quite clear: "In executory Agreements, if the Contract be, that one shall do an Act, and for the doing thereof, the other shall pay \&c. the Performance of the Act is a Condition preecedent [sic] to the Payment. Except 1, a Day appointed for Payment of the Money happen before the Thing can be performed. For in this case it is plain the Party relied upon his Remedy." Id. at 4-5. Adams states the rule with respect to mutually independent promises quite clearly in a passage Horwitz does not quote: "In Case of mutual Promises, one Promise is the Consideration of the other. And in these Cases the Plaintiff is not obliged to aver Performance of his Part." Id. at 20.

" $1 \mathrm{Z}$. Swift, A System of the Laws of the State of Connecticut 380-81 (Windham 1795).

${ }^{75}$ Horwitz, supra note 1 , at 930 . 
states what had long been the law and long would be. So far as promise-for-promise cases are concerned, Swift explains that mutual promises can be consideration for each other, but only if the parties so intended. ${ }^{76}$ Whether the parties contracted on the basis of mutual promises or on the basis that part performance was required for any obligation to arise is a question of inference from the facts. Swift also explains the mutual dependence rules and gives a particularly clear account of how such rules worked in the law of sale. ${ }^{77}$

Finally, it is difficult for me to comment on Horwitz's use of Muir v. Key ${ }^{78}$ (Virginia 1787) because I have not had access to the manuscript in which the case is reported. From Horwitz's account of the dispute in the case, the issue apparently turned on the application of the rules on mutual dependence of promises. Here, as with Swift, I must again emphasize that it was only because of the recognition of promise-for-promise contracts that all the complex rules of mutual dependence became necessary. Horwitz fails to appreciate the complexity and the function of the rules governing bilateral contracts, which had been settled in all essentials in the sixteenth and seventeenth centuries.

\section{B. The Award of Expectation Damages}

Horwitz places considerable emphasis on the alleged failure of the courts in the eighteenth century to award "expectation damages." He argues that the law first adopted the expectation principle in the $1790 \mathrm{~s}$, in cases involving speculative dealings in stock. ${ }^{79}$ The principle then passed into the law of sales and presumably elsewhere. Horwitz links the refusal to award expectation damages before the 1790s to his "title theory of exchange," and the adoption of the new principle to the alleged rise of the executory contract and the beginning of the separation of contract and property law:

[T] $\mathrm{The}$ recognition of expectation damages marks the rise of the executory contract as an important part of English and American law. Furthermore, the moment at which courts focus on expectation damages, rather than restitution or specific performance to give a remedy for non-delivery, is precisely the

1 Z. SwIFT, supra note 74, at 375-76 (citing Nichols v. Raynbred, Hob. 88, 80 Eng. Rep. 238 (K.B. 1615)), 380.

"Id. at 375 .

7x This was cited by Horwitz, supra note 1, at 929-30, 929 n.64 (ms. in Tucker-Coleman Collection, Swen Library, College of William \& Mary).

" Horwitz, supra note 1, at 937 . 
time at which contract law begins to separate itself from property. ${ }^{80}$

It is somewhat surprising that Horwitz contrasts specific performance and expectation damages as if they embodied antithetical policies or theories. The idea of distinguishing, for analytical purposes, damages awarded on an "expectation" basis stems from the celebrated article by Fuller and Perdue in $1936 .{ }^{81}$ Fuller and Perdue distinguish a restitution interest, a reliance interest, and an expectation interest. There are two ways to protect the expectation interest: award damages calculated as being the value of performance, or award specific performance. ${ }^{82}$ Insofar as the Court of Chancery awarded specific performance long before 1790 , it was not giving expectation damages, but it was vindicating the expectation interest.

When Powell wrote in 1790 that specific performance would be given for a contract to deliver stock, he was recognizing the expectation principle, not adopting some antithetical principle as Horwitz appears to claim. ${ }^{83}$ Indeed, the passage that Horwitz cites in Powell,

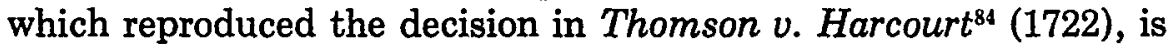
a strong example of recognition of the expectation principle. The defendant had refused to accept delivery of stock in a falling market. Although the court held that the contract was rendered par-

Id. at $936-37$.

s) Fuller \& Perdue, The Reliance Interest in Contract Damages (pts. 1 \& 2), 46 YALE L.J. 52, 373 (1936-1937).

x2 Id. at 54. In passing, two points are worth noting. First, much of the nineteenthcentury case law on the assessment and measure of damages centered upon the scope of the expectation principle, or, how generously performance was to be valued. Second, the scheme of thought in which problems were presented (for example, whether loss of profits should be awarded) was not that of Fuller and Perdue. Contemporaries had no opportunity to read that justly famous contribution to the subject; they did not analyze problems in terms of "interests." Their basic scheme of thought was causal: did the breach cause the loss for which the damages were claimed?

* Horwitz writes that "as late as 1790 , John Powell concluded that specific performance, and not an action for damages, was the proper remedy for failure to deliver stock in a rising market." Horwitz, supra note 1, at 937 (citing 2 J. PowELL, supra note 50, at 232-33). In the passages just before and just after the one cited, Powell discusses circumstances under which "the plaintiff ought to be left to make the most of it he can at law, and not aided by a court of equity." Id. at 232 . He contrasts these with the case of a failure to deliver stock, in which specific performance was normally granted. Although the plaintiff in the case to which Powell refers was enjoined from pursuing his remedy at law, Thomson v. Harcourt, 1 Brown 193, 198, 1 Eng. Rep. 508, 512 (H.L. 1722), Powell nowhere says that specific performance was the exclusive remedy allowed in such cases. In practice, in a rising market plaintiffs would normally prefer specific performance to damages measured as of the date on which delivery had been due. Thomson $v$. Harcourt concerned failure to accept delivery in a falling market.

${ }^{84} 1$ Brown 193, 1 Eng. Rep. 508 (H.L. 1722). See text at notes 166-168 infra. 
tially void by statute, it also held that the defendant had to accept delivery of part of the stock he had contracted to buy at the higher, agreed-upon price. Powell comments that, on the same principle, when the price has risen, a seller in breach would be ordered to transfer the stock at the agreed-upon price and "to account for all the dividends from the time at which it ought to have been transferred."'ss Thus, an order to pay money would be tacked on to a decree to provide specific performance, putting the contracting party into the position in which he would have been had the contract been performed on time.

Horwitz's argument must therefore be limited to the assertion that the expectation principle was not adopted at common law in actions for money damages. Before examining the evidence, I should like to make two preliminary comments. Horwitz relates the alleged failure of pre-1790 courts to award expectation damages to the alleged lack of separation between the law of contract and that of property; he sets up an antithesis between his "title theory of exchange" and the award of expectation damages. This is an odd antithesis. As Fuller and Perdue point out in their discussion of the justification for protecting the expectation interest:

The essence of a credit economy lies in the fact that it tends to eliminate the distinction between present and future (promised) goods. Expectations of future values become, for purposes of trade, present values. In a society in which credit has become a significant and pervasive institution, it is inevitable that the expectancy created by an enforceable promise should be regarded as a kind of property, and breach of the promise as an injury to that property. ${ }^{86}$

Indeed, if contract is seen as a mechanism for granting property rights, the natural measure of damages will be the value of that property, which is the measure of expectation damages.

Moreover, it is a historical misconception to suppose that before the nineteenth century there were settled legal rules or principles governing damage assessment, which had to be correctly explained in directing juries if the verdict was to stand. ${ }^{87}$ As Horwitz

* 2 J. PowsLL, supra note 50, at 232-33. See also Gardener v. Pullen \& Phillips, 2 Vern. 394, 23 Eng. Rep. 853 (Ch. 1700), discussed at note 120 infra.

* Fuller \& Perdue, supra note 81, at 59.

" Sedgwick, relying on both the English and American authorities, emphasized this point:

Indeed, for a long time after the distinction between law and fact was established, and the separate province of judge and jury defined with considerable accuracy, there ap- 
concedes, damages were predominantly treated as an unregulated jury matter, and only by slow degrees were rules of law of any kind evolved on this subject. ${ }^{88}$ Judges did sometimes advise and direct juries on assessment, but they recognized that assessment was ultimately a matter within the jury's discretion. In particular, there was an extreme reluctance to interfere with a jury decision on the ground that the damages awarded were too small or too large. There seems to have been no suggestion before $1768^{89}$ that a retrial might be granted on the ground of judicial misdirection regarding the assessment of damages. Indeed, before the nineteenth century, very few cases at all were reported that dealt with the assessment of damages for breach of contract.

It is of course reasonable and historically legitimate to try to discover what assumptions guided a practice that eventually hardened into law. Eighteenth-century jurists undoubtedly had ideas about the proper way for the jury to set about its task, and some of these ideas may eventually have become canonized. But certain obstacles inevitably hamper investigations into judicial practices that have not yet become regulated. The first is that in the absence of any form of review designed to achieve uniformity, the practice may not have been uniform, either at one time, or over a period of time; different and imprecise ideas may have been current. Second, since damage assessment was largely viewed as a jury matter, the law reports were little interested in the subject. Third, what the

pears to have been an almost total want of any clear and definite understanding of these rules of damages which we now have to consider.

1 T. Sedgwick, A Treatise on the Measure of Damages § 19, at 14-15 (9th ed. 1912) (1st ed. New York 1847).

** Horwitz, supra note 1 , at $925-26$. The best treatment of the subject is Washington, Damages in Contract at Common Law (pts. 1 \& 2), 47 L.Q. REv. 345 (1931), 48 id. 90 (1932). The point made in the text is very apparent from the earliest treatise on the subject, J. SAYER, The LAw of Damages (Dublin 1792), particularly chapters 30-33, at 197-237, dealing with the granting of a new trial or a new writ of enquiry on account of the smallness or excessiveness of the damages awarded.

89 Smee v. Huddlestone (C.P. 1768), noted in J. SAYER, supra note 88, at 49-52. It seems to have been assumed in the eighteenth century that a misdirection could be a ground for a new trial. In the classic description of the system, one of the grounds stated for the grant of a new trial is the misdirection of the judge. 2 W. Tidd, The Practice of the Courts of King's Bench and Common Pleas 907 (9th ed. London 1828) (1st ed. London 1790). In fact, however, instances of this happening in the eighteenth century were rare. The practice appears to have begun in Holt's time. See No. 24 Anon., 2 Salk. 649, 91 Eng. Rep. 552 (K.B. 1702). See also How v. Strode, 2 Wils. 269, 95 Eng. Rep. 804 (K.B. 1765). In his account of the procedure at a trial, which is very detailed, Tidd does not discuss the directing of juries. The following quotation is all we get: "The evidence being gone through, and summed up by the judge, the jury, if they think proper, may withdraw from the bar, to deliberate on their verdict." $2 \mathrm{~W}$. Trod, supra, at 867. 
reporters tended to record was the unusual and not the normal.90 With these points in mind, I now turn to a consideration of the evidence on Horwitz's claim that the measure of damages at common law for breach of contract was restitutionary until the 1790s."

1. Measures of Damages in the Sixteenth, Seventeenth, and Eighteenth Centuries. The claim that restitution was once the measure of damages at common law for breach of contract has in fact been advanced before by Williston ${ }^{92}$ and Ames, ${ }^{93}$ but only with reference to the fifteenth- and sixteenth-century history of assumpsit, where it has long been shown to be incorrect. ${ }^{94}$ When applied to the law of the seventeenth and eighteenth centuries, this conclusion bristles with difficulties that Horwitz does not discuss at all. A law of contract based wholeheartedly upon the restitutionary principle would have differed quite radically, in both its general structure and its details, from the law of assumpsit in the eighteenth century and earlier.

If one considers the purest example of actionable mutual promises, the wager, under restitutionary principles the only possible remedy would be recovery of the stake if it had been prepaid. But it is quite undisputed that wagers were not prepaid and yet were enforced. In the case of a sale of goods, under restitutionary principles the buyer's remedy would be only an action to recover a prepayment. Yet as far back as I am aware, courts awarded damages measured by the value of the bargain, though peculiar facts may sometimes have cast doubt on whether this was the proper measure to apply in the circumstances. In pre-assumpsit days, in a sale of fungibles, the buyer's remedy was debt "in the detinet," with judgment for the price or value of the goods; price and value may not have been distinguished..$^{95}$ But as soon as assumpsit came to be used, the

so This surely is the explanation for the reporting of Nurse v. Barns, T. Raym. 77, 83 Eng. Rep. 43 (K.B. 1663), and James v. Morgan, 1 Lev. 111, 83 Eng. Rep. 323 (K.B. 1663), discussed in A. Simpson, supra note 42, at 585-86 (where James v. Morgan is mistakenly rendered Jones $v$. Morgan).

" Specific performance can be set to one side. It is, as we have seen, merely an application of the expectation principle. See text and notes at notes 81-82 supra.

33 S. Williston, The Law of Contracts $\$ 1338$, at 2393 (1920).

33 J. Ames, Lectures on Legal History 143-44 (1913). See A. Simpson, supra note 42, at 582.87.

"Id. at 56-57; Washington, supra note 88, 47 L.Q. Rev. at 371-79.

ss See A. Simpson, supra note 42 , at 56-57. Horwitz claims that "goods came to be thought of as fungible" only late in the history of contract. Horwitz, supra note 1, at 918 . This claim is susceptible to two interpretations. It could mean either that contracts for the sale of nonspecific goods by number, weight, or measure were not made or litigated, or that lawyers did not grasp the conceptual difference between specific and fungible goods. Regardless which view Horwitz intended, his claim seems impossible to square with the evidence. 
concept of loss caused by the breach brought up the idea of a comparison between the market and the contract price.

In one of the earliest known cases on assumpsit for failure to deliver, Pykeryng $v$. Thurgoode $e^{96}$ (1532), there is no suggestion that the action was conceived as confined merely to the recovery of prices partially prepaid. This was a brewery case; the plaintiff alleged that through failure to deliver, "he was left without malt and compelled to buy malt at a far greater price."97 What was claimed and awarded was apparently the downpayment plus the difference between the contract price and the higher market price. ${ }^{98}$

Again, the elaborate rules regarding the mutual dependence of promises ${ }^{99}$ would have had no function at all in a world in which contractual remedies were restitutionary only, leading to the recovery of money paid or property (or its value) handed over. Horwitz's thesis is not developed to a point at which it is possible to see how he would deal with difficulties of these kinds, nor does he explain how the quasicontractual or restitutionary remedies evolved in the seventeenth and eighteenth centuries were needed in a world in which all assumpsit actions were merely restitutionary. His argument is essentially negative, and in specific terms it relies on two cases: Flureau v. Thornhill ${ }^{100}$ and Dutch $v$. Warren ${ }^{101}$ The argument is that these cases do not establish the expectation principle, with the implication that they reflect the general acceptance of restitution as the measure of damages in contract law. ${ }^{102}$

In Flureau v. Thornhill ${ }^{103}$ (1776), plaintiff purchased a rent at

Such contracts existed and they were not rare exceptions. For examples of litigation in assumpsit on such contracts, see Orwell v. Mortoft, Y.B. $20 \mathrm{Hen}$. VII, 8 pl. 18 (C.P. 1505); Norwood v. Read, 1 Plowd. 180, 75 Eng. Rep. 277 (K.B. 1558); Pykeryng v. Thurgoode (K.B. 1532), reported in 2 SpelmaN's Reports 247 (Selden Soc., J. Baker ed. 1978). The early law is discussed in J. Baker, Introduction, in id. at 275-86. See also Milsom, Sale of Goods in the Fifteenth Century, 77 L.Q. REv. 257 (1961).

${ }^{86}$ (K.B. 1532), reported in 2 SpELman's ReporTs, supra note 95, at 247. The case is discussed by Baker, Introduction, id. at 283-85.

${ }^{97}$ (K.B. 1532), reported in 2 SPELMAN's REPoRTs, supra note 95, at 247, 248.

98 Although it is impossible to tell exactly how the damages were awarded, the explanation I have offered is also the one given by Baker, Introduction, in id. at 284. Baker cites several other cases from this period in which juries awarded damages comprising the return of the down payment (or the sum lent) and the difference between contract and market price (or, where appropriate, loss in rent). Id. at nn.2-4.

${ }^{29}$ See text and notes at notes 57.58 \& 77 supra.

${ }_{100} 2$ Black. W. 1078, 96 Eng. Rep. 635 (C.P. 1776), discussed in Horwitz, supra note 1, at 921

1011 Strange 406, 93 Eng. Rep. 598 (K.B. 1720), more fully reported in Moses v. Macferlan, 2 Burr. 1005, 1011-12, 97 Eng. Rep. 676, 680 (K.B. 1760).

${ }^{102}$ Horwitz, supra note 1, at 920-22.

${ }_{103} 2$ Black. W. 1078, 96 Eng. Rep. 635 (C.P. 1776). 
auction and paid a deposit of $£ 54$. The defendant was unable to make title and offered to go ahead on a defective title or to return the deposit with interest and costs. The plaintiff rejected the offer and sued for damages for the loss of a good bargain. The jury, contrary to the direction of the trial judge, awarded damages of $£ 20$ as well as the return of the deposit. Evidence had been given at the trial that the plaintiff had sold stock disadvantageously to raise the purchase price, but the amount involved had not been quantified. There had also been conflicting evidence relating to the question whether the bargain was a good one.

The ruling, stated only by Grey, C.J., was that "[u]pon a contract for a purchase, if the title proves bad, and the vendor is (without fraud) incapable of making a good one, I do not think that the purchaser can be entitled to any damages for the fancied goodness of the bargain, which he supposes he has lost."104 Insofar as any discernible principle lies behind this ruling, it would appear to be an objection to the speculative or conjectural character of the claim. Blackstone (speaking judicially) gave a different reason for the result. "These contracts are merely upon condition, frequently expressed, but always implied, that the vendor has a good title. If he has not, the return of the deposit, with interest and costs, is all that can be expected." 105 For Horwitz, this case shows that eighteenthcentury courts rejected the expectation principle and awarded only restitution damages. It appears to me that had it been the general rule in actions of special assumpsit (as well as in actions for money had and received) that only restitution was possible, this general rule would have been given as a reason by at least one of the judges whose opinions are reported, and there would have been no need to justify the result in terms of an implied condition. Instead, the court appears to be justifying something in the nature of an exception. ${ }^{106}$

Dutch v. Warren ${ }^{107}(1720)$, Horwitz's other specific evdence, is a case in which an action for money had and received to the plain-

tou Id. at 1078, 96 Eng. Rep.' at 635.

${ }^{105}$ Id. at $1078-79,96$ Eng. Rep. at 635.

108 The only earlier case directly dealing with the same matter seems to be Brig's Case, Palmer 364, 81 Eng. Rep. 1125 (K.B. 1623), in which there had been prepayment of a fine (i.e., lump sum) on purchase of a lease. It held, on facts somewhat similar to those of Flureau, that the proper form of action was "an action on the case for loss of the benefit of the bargain, and he will not only recover the money he gave by way of a lump sum payment, but damages in addition for the breach of contract." Id. This holding is of course incompatible with that of Flureau.

${ }_{107} 1$ Strange 406, 93 Eng. Rep. 598 (K.B. 1720), more fully reported in Moses v. Macferlan, 2 Burr. 1005, 1111-12, 97 Eng. Rep. 676, 680 (K.B. 1760). 
tiff's use was brought against a defendant who had been paid $£ 262$ 10 s for five shares in a copper mine to be transferred when the books of the company opened. But when the books opened, the defendant refused to transfer the stock, although it had declined substantially in value since the date of the contract; nor would he return the deposit. The question of interest to the present discussion was whether the plaintiff should recover the sum paid over, $£ 26210$ s., or the value of the shares at the date'for delivery, $£ 175$. The court followed the latter view. This holding did not restore the plaintiff to the position in which he had been before the bargain was made, but gave him the "benefit" of the bargain. Although the plaintiff asked for restitution, the holding rests squarely on the expectation principle. ${ }^{108}$ It is an inconceivable holding unless it was then thought that the correct measure of damages for breach of an agreement was the value of performance generally: it would make no sense for the value of performance to be the measure of recovery in a falling market but not in a rising one, with one exception to which I now turn.

In Moses v. Macferlan ${ }^{108}$ (1760), Mansfield, C.J., followed and approved Dutch $v$. Warren, adding, however, that "[i]f the five shares had been of much more value, yet the plaintiff could only have recovered the $262 f 10 \mathrm{~s}$. by this form of action."110 The implication may be that in a rising market the plaintiff should have used a different form of action, special assumpsit; the point Mansfield was making is that in the action for money had and received recovery was limited, at most, to the sum alleged to have been received."11 Mansfield also glossed the earlier case by claiming that it had been only "against conscience" for the defendant to retain both the shares and their value, the sum of $£ 175 .{ }^{112}$ This reference to "conscience" as the basis of decision is not to be found in the report of the case, and, as Horwitz points out, ${ }^{113}$ expresses Mansfield's own thesis regarding the "equitable" nature of the action for money had and received. But there is no necessary conflict between understanding this form of action as one based on equitable principles, and recognizing the expectation principle as a measure of damages. Even if Mansfield had been historically correct in attributing the decision in Dutch $v$. Warren to "conscience" or "equity," the

${ }^{103}$ It is therefore misleading, though technically not incorrect, to say that the case was "simply an action for restitution." Horwitz, supra note 1, at 940 n.124.

${ }_{109} 2$ Burr. 1005, 97 Eng. Rep. 676 (K.B. 1760).

110 Id. at 1012, 97 Eng. Rep. at 680.

III This view is criticized by his reporter as mistaken. Id. at 1001, 97 Eng. Rep. at 680 . 112 Id.

${ }^{113}$ Horwitz, supra note 1, at 922. 
case still recognizes clearly that the essential duty of a contracting party is to confer upon the other the value of performance, and that is the expectation principle.

The best reason for thinking that the matter had long been settled is the absence of cases in the eighteenth century canvassing the choice between alternative approaches. Dutch $v$. Warren is not the only early eighteenth-century case that apparently assumes the expectation principle. Peeram v. Palmer (1712), reported in Gilbert's The Law of Evidence, ${ }^{114}$ involved a contract for the sale of 100 quarters of barley at a contract price of 16 a quarter, part being prepaid and the balance payable on delivery, which was to take place at the purchaser's malt house between harvest and Candlemas. The defendant vendor made short delivery only two days before Candlemas. The plaintiff retaliated by paying only part of the agreed price in ready money at that time. He did pay in full before bringing the action, but the rest of the malt was never delivered, perhaps because of the quarrel over the incident. The jury assessed £4 damages for the failure to deliver the balance and found, by agreement between the parties, a special verdict. The case was argued before Parker, C.J., as raising problems regarding the mutual dependence of promises in executory contracts; the rules for assessing damages were not discussed. The agreed special verdict, however, includes this finding: "That the Price of Barley between the Time of the Contract and the Delivery of the said twenty Quarters rose about, etc."'115 It is difficult to explain this verdict unless the orthodox expectation-damage rule was then a normal assumption, there being otherwise no purpose in such finding of fact. The case would, indeed, be wholly unintelligible in terms of a restitutionary theory of damages.

Clear confirmation of the application of the principle of expectation damages in contracts for the sale of goods in the early eighteenth century is also found in the history of the enforcement of contracts for the sale of stock. Although Horwitz gives the impression that such contracts were a late eighteenth-century phenomenon, this is not so. ${ }^{116}$ The South Sea Bubble, which "burst" in 1720, had familiarized everyone with them, and even before this there was law on the subject. It came to be settled in the nineteenth century that as a general rule such contracts could not be specifically enforced because damages provided an adequate remedy: the pur-

114 G. Gilbert, The LAw of Evidence 194 (2d ed. London 1756) (1st ed. Dublin 1754).

its Id. at 195.

116 See note 35 supra. 
chaser could go into the market and buy stock, and he would suffer no loss because the common law would compensate him in expectation damages for any loss due to market fluctuations. ${ }^{17}$ This doctrine is first clearly found much earlier than Horwitz supposes; in Cud v. Rutter ${ }^{118}$ (1719), a decree by the Master of the Rolls awarding specific performance was reversed by Parker, L.C., who explicitly relied on the rule at law for the assessment of damages for failure to deliver goods. Instancing a sale of grain to be delivered on a stated day in a market, Parker said: "[T]he buyer is left to his remedy at law for breach of the agreement, to recover damages, (id est,) the difference between the price agreed on by the parties, and the price of corn upon the market day."119

Even earlier than this, in Gardener v. Pullen \& Phillips ${ }^{120}$ (1700), there appears to be a recognition of the same basic approach to contractual liability, though the decision is contrary. A penialty bond of $£ 500$ was conditioned on the transfer of $£ 300$ stock in the old East India Company. The principle was by then established that relief from the penalty could be obtained on the payment of proper compensation, and since the contract date the stock had risen sharply in value. Two solutions were offered: the defendant might be required to pay the value at the date of the delivery (and account for dividends due since then) or actually to transfer 1300 nominal value of stock (worth much more on the market). The court adopted the latter solution. It is noteworthy that both solutions assume that the policy is to put the contracting party into the position he would have been in if the contract had been performed. ${ }^{121}$

2. The "Transformation" of the Law of Damages. Horwitz contends ${ }^{122}$ that in England the "leading case" introducing the expectation principle was Shepherd v. Johnson ${ }^{123}$ (1802), which dealt with the replacement of stock on a rising market. In fact, as the report makes clear, "the only question was, whether the damages should be calculated at $1133 £ 18 \mathrm{~s}$. $6 \mathrm{~d}$., the price of the stock on the 1st of August when it was to be replaced [i.e., the date of performance

117 See Deloret v. Rothchild, 1 Sim. \& St. 590, 57 Eng. Rep. 233 (Ch. 1824); Nutbrown v. Thornton, 10 Ves. Jun. 159, 32 Eng. Rep. 805 (Ch. 1804).

${ }^{118} 1 \mathrm{P}$. Wms. 570, 24 Eng. Rep. 521 (Ch. 1719), noted in 5 Vin. Abr. 538, pl. 21.

115 Vin. Abr. at 539.

1202 Vern. 394, 23 Eng. Rep. 853 (Ch. 1700).

121 Stent v. Bailis, 2 P. Wms. 217, 24 Eng. Rep. 705 (Ch. 1724), states an exception that is quite compatible with the main principle: equity might order the buyer to accept delivery where the stock had fallen by the date for delivery, but not where the company had collapsed, refused to transfer the shares on its books, and did not expect ever to reopen its books.

122 Horwitz, supra note 1, at 937 n.101.

เz 2 East 211, 102 Eng. Rep. 349 (K.B. 1802). 
due]; or at $1224 \mathrm{f} 1 \mathrm{~s}$. the price of the stock on the day of the trial." 124 A case cannot be regarded as a leading case establishing a principle that was never in dispute in the case. The expectation principle was assumed in Shepherd. ${ }^{125}$ All that was at issue was its precise application: Was the value of performance to be measured as of the date of performance or the date of the trial? ${ }^{126}$

The basic principle of expectation damages was not a subject of argument in any of the numerous cases dealing with this and similar points in the law of sale of goods; nor was it ever contended that the purchaser could obtain only restitution. ${ }^{127}$ From this I conclude that the award of expectation damages was the norm, that the matter was not controversial, ${ }^{128}$ and that the cases at the turn

124 Id. at 211, 102 Eng. Rep. at 349-50.

125 It was apparently also assumed in Sanders v. Kentish \& Hawksley, 8 T.R. 162, 101 Eng. Rep. 1323 (K.B. 1799), discussed in Shepherd v. Johnson, 2 East. 211, 212, 102 Eng. Rep. 349,350 (K.B. 1802). See also cases collected in note 127 infra.

${ }_{126}$ The principle established in the stock cases was that where the defaulting party had the use of the plaintiff's money, as in the case of a loan of stock, or where there had been prepayment, the measure of damages where stock had risen was calculated on the basis of the value of the stock on the date when delivery had been due or on the date of the trial, but not at any intermediate point. See Shepherd v. Johnson, 2 East 211, 102 Eng. Rep. 349 (K.B. 1802); Owen v. Routh, 14 C.B. 327,139 Eng. Rep. 134 (C.P. 1854); M'Arthur v. Lord Seaforth, 2 Taunt. 257, 127 Eng. Rep. 1076 (C.P. 1810); Harrison v. Harrison, 1 Car. \& P. 412, 171 Eng. Rep. 1253 (1824) (nisi prius); Downes v. Back, 1 Stark 318, 171 Eng. Rep. 485 (1816) (nisi prius). In Sanders v. Kentish \& Hawksley, 8 T.R. 162, 101 Eng. Rep. 1323 (K.B. 1799), where the price of the stock fell between the date delivery was due and the date of the trial, the court took the view that the value at the date of delivery was the correct rule. The issue was long debated in American law. See, e.g., 4 T. SeDGwick, supra note 87, §1256j, at 2586-87.

127 Of the English cases cited by Horwitz, supra note 1, at 940 n.123, none involves the least suggestion that the expectation principle was in doubt. Leigh v. Paterson, 8 Taunt. 540, 129 Eng. Rep. 493 (C.P. 1818), holds that the last day for delivery is to be the moment for applying the contract-price/market-price rule. Gainsford v. Carroll, 2 B. \& C. 624, 107 Eng. Rep. 516 (K.B. 1824), distinguishes the stock cases as being cases in which the plaintiff did not have the use of his money and therefore could recover on the basis of the market value at the time of trial and not when delivery had been due. Greening v. Wilkinson, 1 Car. \& P. 625, 171 Eng. Rep. 1344 (1825) (nisi prius), is in fact an action of trover, and is therefore not directly relevant; it appears to have disapproved Mercer v. Jones, 3 Camp. 477, 170 Eng. Rep. 1452 (1813) (nisi prius). The decisions on trover assumed that the measure of damages was the value of the goods, but differences arose about whether this should be calculated at the date of conversion or, when values fluctuated, at some later date.

${ }^{123}$ Horwitz states that Powell's "only recognition of the effect of changes in the market on contracts of sale is his statement that if, after a contract for delivery of corn, the price falls to 5 pounds, the buyer "will be entitled either to . . . [the] corn, or five pounds," and that Powell's chapter on damages does not mention expectation damages. Horwitz, supra note 1, at $940 \mathrm{n} .124$ (quoting $1 \mathrm{~J}$. Poweld, supra note 50, at 409). This is misleading. Powell states this principle on the page from which Horwitz took the quotation:

But if, by reason of improper delay, the value of the subject stipulated about is varied between the time of the contract being made, and its being performed, the loss must be 
of the century are refining a received principle in detail, this refinement going hand in hand with increased supervision of jury awards.

As for the American cases, Horwitz argues that here, too, the expectation-damage rule entered through cases dealing with stock. ${ }^{129}$ The implication is that it replaced some other rule, presumably based on restitution. Part of Horwitz's argument involves the implication that the courts were hesitant in adopting the novel approach. The cases simply fail to support this interpretation.

In Pennsylvania, the earliest recorded decision is Lewis $v$. Carradan $^{130}$ (1786), which deals with a sale of wheat, not stock, and states that "the rule or measure of damages in such cases is to give the difference between the price contracted for and the price at the time of delivery."131 In the context, this measure of damages is not presented as an innovation, and the case goes further in envisaging possible recovery for loss or profits. Horwitz attempts to minimize the importance of this decision as "this one exception," 132 but this explanation will not do. The case shows that as early as 1786 courts applied the expectation principle to the sale of goods without any hint that they were doing something novel.

Another Pennsylvania case, Marshall v. Campbell ${ }^{133}$ (1791), quite explicitly applies the sale of goods rule to stock: the decision is based on the earlier unpublished opinion in Lewis $v$. Carradan, ${ }^{134}$ a reliance dismissed by Horwitz as "anomalous."135 Among the authorities relied on in Marshall are the English decisions in Gardener v. Pullen \& Phillips $^{136}(1700)$ and probably either Cud v. Rutter (1719) or Dorison v. Westbrook (1721). ${ }^{137}$ There is no suggestion in

borne by the party who was to carry the contract into execution; as if one were bound under a penalty to transfer stock at a given time, and he neglected so to do, and the stock rose in the mean time; he should transfer the stock stipulated in specie, and not so much as it was worth, on the day when he ought to have transferred it.

$1 \mathrm{~J}$. Powell, supra note 50, at 409. Powell's reference is to Gardener v. Pullen \& Phillips, 2 Vern. 394, 23 Eng. Rep. 853 (Ch. 1700), with a quaere. See text at notes 85 and 120 supra. Powell's formulation of the principle in terms of risk produces the same result as the expectation principle.

120 Horwitz, supra note 1, at 937.

130 Unpublished opinion; the Chief Justice's notes on the case are quoted at length in Marshall v. Campbell, 1 Yeates 35 , 36-37 (Pa. 1791). See Horwitz, supra note 1, at 940 n.121.

131 Marshall v. Campbell, 1 Yeates 35, 37 (Pa. 1791).

132 Horwitz, supra.note 1, at 940.

1331 Yeates $35(\mathrm{~Pa} .1791)$.

134 Id. at 36.

135 Horwitz, supra note 1, at 940 . The decision is actually based on two earlier cases: Cox v. Fox and Lewis v. Carradan, both apparently unpublished.

${ }^{136} 2$ Vern. 394, 23 Eng. Rep. 853 (Ch. 1700). See tèxt at note 120 supra.

1371 P. Wms. 570, 24 Eng. Rep. 521 (Ch. 1719), noted in 5 Vin. Abr. 538, p1. 21 at 540. See text at note 118 supra. The reference in Marshall $v$. Campbell is not to the name of the 
Marshall of any alternative approach to the assessment of damages. Pennsylvania cases in $1793,{ }^{138} 1795,{ }^{139}$ and $1796^{140}$ follow the same doctrine. As Horwitz himself points out, ${ }^{141}$ the courts say nothing in these cases to suggest that they are introducing a radically new principle for determining damages.

In Virginia, the basis for the supposed transformation is Groves $v$. Graves ${ }^{142}(1790)$. Groves concerned a contract for the payment of $£ 260$ on a specified date, payable in stock certificates at an agreed valuation: $26 \mathrm{p}$. (the market price at the date of contracting) per. $£ 1$ nominal value if paid on time, and $13 \mathrm{p}$. in case of default. The underlying transaction was a loan, and the contract merely made the normal provision of a double sum as penalty, adapting the form of contract to the exigencies of an economy short of specie. The jury awarded the penalty and used for valuation purposes the market value at the date of trial. The Chancellor enjoined enforcement of the decree. The Virginia Court of Appeals reversed the Chancellor, but it held the jury's award incorrect on two accounts: what should have been awarded was only the market value (that is, the nonpenal valuation), and this at the date of delivery, not the date of the trial. ${ }^{143}$ Again, there is no hint in the case that there was anything novel or controversial in the adoption of the expectation principle. The case is merely concerned with its application to this particular contract.

In South Carolina, the first case that Horwitz uses is Davis $v$. Richardson ${ }^{144}$ (1790), concerning a loan of Carolina stock with a contract to repay in stock. In argument, Counsel contended:

It was therefore exactly similar to the sale or contract for stock in England. That in all cases, where a specific thing or property of any kind is to be delivered, and the party fails in delivering it, the value of the property at the time of delivery, and not the value at the time of contract, is the true and governing rule of estimation. ${ }^{145}$

case, but to 5 Vin. 510 , which must surely be a slip for 5 Vin. 538 , on which Cud v. Rutter is found (pl. 21), or 5 Vin. 540, pl. 22, which reports Dorison v. Westbrook (Ch. 1721).

iss Livingston v. Swanwick, 2 Dall. 300 (C.C.D. Pa. 1793).

139 Gilchreest v. Pollock, 2 Yeates 18 (Pa. 1795).

110 Graham v. Bickham, 4 Dall. 149 (Pa. 1796).

11 Horwitz, supra note 1, at 939 n.119.

1121 Va. (1 Wash.) 1 (1790), discussed in Horwitz, supra note 1, at 939.

$1 / 31 \mathrm{Va} .(1 \mathrm{Wash}$.$) at 3$.

141 S.C.L. (1 Bay) 105 (1790), discussed in Horwitz, supra note 1, at 937.

us 1 S.C.L. (1 Bay) 105, 106 (1790) (italics omitted). At this date there was no rule of expectation damages in England, according to Horwitz, supra note 1, at 937, but his view 
The court did not find the case problematic: "[This is not a case of difficulty in settling the principle, but] it is of extensive importance to the community that the principle should now be settled and ascertained with precision. " 146 The court addressed itself to this task and ruled that if no date for delivery was fixed, the value must be taken at the time of trial. The issue in the case was not the more general question of choosing between expectation damages and some alternative approach.

Horwitz claims that the later case of Atkinson v. Scot ${ }^{147}$ (1793) shows that the expectation rule was under attack: he states that Charles Pinckney argued there "that the allowance of expectation damages was nothing more than the allowance of usury." 148 In fact, Pinckney never made so bizarre a claim. The underlying transaction involved in Atkinson was a loan for one year. Debt was brought on a bond conditioned on repayment of an indent (a government bond). The plaintiff attempted to argue that a subsequent parol agreement had been made providing that if the indent was not returned on the day fixed in the condition, it should be converted into a specie debt and paid at the nominal value, pound for pound. Pinckney argued, first, that parol variation was impossible, and, second, that if it was allowed, the transaction would plainly be usurious as vastly exceeding the permitted rate of interest, because the nominal value of the indent (some 11267) was about eight and one-half times its market value of some $£ 150$. The court, relying on Davis $v$. Richardson, with which Pinckney did not quarrel, agreed and applied the expectation rule: the plaintiff was entitled to what he had the right to expect, the return of his loan (in indents or equivalent value in specie) with normal interest. ${ }^{149}$

Horwitz is wrong in supposing from the case that the stock had appreciated 850 percent and that the case concerned speculation in a rising market. We are not told in the case whether the stock had risen at all. We are told only that the stock was worth-presumably at the time of the trial, but quite possibly at the time of the loan as well-less than its face value, $£ 850$ nominal being worth approximately $£ 100$ specie. The issue in the case was whether an 850 percent penalty clause (added in a parol agreement at that) should be

obviously not held in South Carolina in 1790. Counsel relied on Gardener v. Pullen \& Phillips, 2 Vern. 394, 23 Eng. Rep. 853 (Ch. 1700).

${ }_{166} 1$ S.C.L. (1 Bay) at 106 . Horwitz, supra note 1 , at 938, quotes this sentence without the first clause, which I have bracketed.

147 S.C.L. (1 Bay) 307 (1793).

us Horwitz, supra note 1, at 938.

1191 S.C.L. (1 Bay) at 309. 
enforced; the issue was not, as Horwitz interprets it, whether a rising market makes expectation damages usurious.

In sum, the known American cases do not support the picture presented by Horwitz of a transformation of the law of measure of damages. The stock cases applied the established common-law rule governing sale of goods to the sale of stock and refined the details of that rule. The doctrine was probably derived from English law. Quite aside from his misreading of some of these cases, Horwitz adopts a fundamentally misconceived approach to his evidence. Even when he is aware that a case assumes the expectation principle and deals only with problems of its application, the absence of earlier reported cases on damages in a particular state leads Horwitz to conclude that the case under discussion introduced the expectation principle for the first time in that state. Although this might happen occasionally, it is inconceivable that a new principle could be introduced in state after state without a hint of its novelty. Indeed, it is a telling point against Horwitz's supposed conflict between "equitable" and capitalist-serving principles that none of the cases even hints at the existence of any dispute about whether expectation is the correct general principle for the assessment of damages. ${ }^{150}$

\section{Specific Performance and Inadequacy of Consideration}

Horwitz asserts that in the eighteenth century there was a "well-established doctrine that equity courts would refuse specific enforcement of any contract in which they determined that the consideration was inadequate." 151 This doctrine, Horwitz implies, was the clearest example of the persistence of just-price conceptions in the eighteenth century. Horwitz argues generally that the text writers on contract law, ${ }^{152}$ beginning with Powell in 1790, attacked doctrines of the just price. ${ }^{153} \mathrm{He}$ presents the rejection of these doctrines by the courts as an important element in the transformation of contract law. ${ }^{154}$

I do not dispute that eighteenth-century courts, like courts in the nineteenth century and today, were occasionally loath to en-

${ }^{150}$ See also Wigg v. Garden, 1 S.C.L. (1 Bay) 357, 358 (1794), in which the court, in response to an argument that in stock cases the value at the date of contract should be awarded, said that it had repeatedly held the correct rule was to award the value at the date of delivery.

ist Horwitz, supra note 1, at 923 (footnote omitted).

${ }^{132}$ Horwitz's analysis of the text writers is criticized in Part III of this article.

${ }^{133}$ See text and notes at notes 20-30 supra.

154 Horwitz, supra note 1, at 923, 947. 
force contracts they considered unfair, whether the unfairness was evidenced by price or other terms. The scanty evidence from the earlier period does not allow us to say whether courts were more likely to disapprove of sharp bargains and to find a way to avoid enforcing them in the eighteenth century than in the nineteenth. The English reports in the eighteenth century do contain a number of cases in which insufficiency or exorbitancy of price is raised in Chancery litigation as a ground for resisting specific performance or rescinding a contract. The evidence for a "well-established doctrine" that equity would refuse specific performance on grounds of mere inadequacy of consideration is very weak, however. The cases are inconsistent, and the poor quality of some of the reports, as well as the presence in most of the cases in point of other factors that may have been regarded as relevant to the decisions, makes it very difficult to derive a doctrine from them with any assurance.

Furthermore, even where equity refused specific performance on grounds, at least in part, of inadequacy of consideration, the bite of such action might have been less painful to the unjust than Horwitz believes. Such refusal would normally refer the plaintiff to his remedy at law, and there, although Horwitz denies it, the normal measure of damages was based on the expectation principle. ${ }^{155}$ The plaintiff might therefore still end up with the financial benefit of his bargain, though recovery was subject to the risk that the jury would refuse to award the full measure of damages ${ }^{158}$ or even that the court itself would find a way, as courts often do, not to enforce a bargain it found unjust. Just-price notions would have their maximum force in those cases in which inadequacy of price was a ground for an equity court not merely to refuse specific performance but to rescind the contract. Cases that even approach such a result are, however, exceedingly rare in the eighteenth century.

1. Eighteenth-Century English Cases. In 1740, in Barnardiston v. Lingood, ${ }^{157}$ Lord Hardwicke did say that " $[i] n$ the case of a hard bargain, where it is not absolutely executed, but executory only, the constant rule of the court is, not to carry it into execution." 158 This is a somewhat narrower doctrine than the one stated by Horwitz. Although courts applied the doctrine in a number of cases in the second half of the eighteenth century, the evidence does not support Lord Hardwicke's claim that it was applied

\footnotetext{
$15 s$ See pp. 547-61 supra.

158 See text at notes $87-89$ supra \& note 241 infra.

1572 Atk. 133, 26 Eng. Rep. 484 (Ch. 1740).

${ }^{158}$ Id. at 134, 26 Eng. Rep. at 485.
} 
before his time, or that it ever became "the constant rule of the court." The early eighteenth-century cases that come closest are a group that arose out of the general fever of speculation associated with the South Sea Bubble around $1720 .{ }^{159}$ In Savile v. Savile, ${ }^{160}$ under what the Lord Chancellor called "a general delusion [of] the nation,"161 an excessive price of $£ 10,500$ was bid at auction for Halifax House in St. James, and a deposit of $£ 1000$ paid. When the buyer refused to go through with the deal, the vendor sued for specific performance. Lord Macclesfield not only refused specific performance, he set aside the contract, thus taking away from the plaintiffvendor his action at law-but only on forfeiture of the deposit, which was tantamount to an award of liquidated damages. ${ }^{162}$

Other cases were less willing to interfere with contract. In Keen $v$. Stuckeley ${ }^{163}$ (1721), a case of exorbitant price, the possibility of refusing specific performance (and leaving the parties to law) was expressly raised and treated as "a very doubtful Point"16s before the Lords. It was left doubtful. ${ }^{185}$ In Thomson v. Harcourt ${ }^{166}$ (1722), another case arising "[d]uring the time of the wicked execution of the South-Sea scheme, and of the general infatuation thereby occasioned,"167 the court did not allow exorbitancy of price as a ground

(3) See also Howell v. George, 1 Mad. 1, 9 n.l, 56 Eng. Rep. 1, 4 n.1 (Ch. 1815), for hints in the very early eighteenth century of a discretion to refuse specific performance for unreasonable contracts or those involving hardship.

160 1 P. Wms. 745, 24 Eng. Rep. 596 (Ch. 1721), abridged in 2 Eq. Ca. Abr. 679, pl. 4, 22 Eng. Rep. 570, pl. 4.

101 Id. at 745, 24 Eng. Rep. at 596, 2 Eq. Ca. Abr. at 679, pl. 4, 22 Eng. Rep. at 570.

112 There was a similar situation in Jennison v. Balkley (Ch. 1721), where the chancellor also discharged the defendant of his contract upon forfeit of his deposit. The case is unreported, but it is mentioned in Savile v. Savile, 1 P. Wms. 745, 748 n.1, 24 Eng. Rep. 596, 597 n.1 (Ch. 1721). The following note, however, makes it clear that "this is not the general law of the Courts; and the decision was probably founded on the general delusion of the times, as taken notice of by Lord Macclesfield." Id. at 748 n.2, 24 Eng. Rep. at 597 n.2.

is Gilb. Rep. 155, 25 Eng. Rep. 109 (H.L. 1721). The decision is also reported under the name Kien v. Stukeley, 1 Bro. 191, I Eng. Rep. 506 (H.L. 1722 [sic]).

i" Gilb. Rep. at 155, 25 Eng. Rep. at 109.

115 The Exchequer, in proceedings on the equity side, had decreed specific performace of this contract for the purchase of land at a price forty times its annual rent. The House of Lords, after debating whether a court of equity should decree specific performance where the bargain appeared to be unconscionable, reversed the Exchequer on the different ground that the plaintiff had failed to perform his side of the bargain because he had not made out the title by the date covenanted. Id. at 156, 25 Eng. Rep. at 109-10. It may not be irrelevant that this case, too, was related to the South Sea Bubble, the defendant claiming that he had offered so much for the land only becuse of the "general delusion, which all men lay under, as to . . . a supposed vast increase of their riches." 1 Bro. at 192, 1 Eng. Rep. at 506.

II 1 Bro. 193, 1 Eng. Rep. 508 (H.L. 1722).

167 Id. 
for refusing specific performance. The parties had agreed to transfer stock with a fare value of $£ 1000$ for $£ 9200$, secured by a penalty bond for $£ 6000$ and the deposit of documents with a stakeholder. The stock was of little value by the time of the final decision; whether the price was exorbitant at the time of the contract is unclear. On the purchaser's failure to accept delivery, the seller commenced an action at law in the Exchequer for damages. The purchaser replied with a bill in equity for relief against the contract, the penalty, and the loss of the deposit. This provoked a cross bill by the seller for specific performance. Holding that the contract was partially rendered void by statute, the Exchequer, in proceedings on the equity side, specifically enforced the remainder, requiring the purchaser to accept delivery of $£ 290$ stock at the same price pro rata ( $£ 920: £ 100$ ) as in the contract. The Lords upheld this decision. Plaintiff's counsel argued successfully that "though the great fall of South-Sea stock might be a general calamity to the nation, yet, as it was not just to relieve one subject against law at the expence [sic] and ruin of another, so neither could it be for the public utility." 168

The first known decisions in which equity refused specific performance and also apparently granted no damages are Lord Hardwicke's own, leading to the suspicion that he was trying to introduce a new principle under the guise of stating an accepted rule. A number of his decisions from 1740 on emphasize the discretionary character of specific performance and suggest a general relief against "hardship."169 But even Lord Hardwicke, who claimed that Chancery would refuse to enforce executory contracts for inadequacy, stated that executed contracts would not be rescinded solely on the basis of inadequacy. ${ }^{170}$ And most of the cases do not go even that far. Barnardiston v. Lingood"171 (1740) involved a bargain with an expectant heir, and such "catching bargains" were sometimes treated as a special category, ${ }^{172}$ though whether this had always been so is unclear. In Buxton v. Lister ${ }^{173}$ (1746), a case involving a contract for the purchase of timber trees, Lord Hardwicke said, "Nothing is more established in this context, than that every agreement of this

${ }^{163}$ Id. at 198, 1 Eng. Rep. at 512.

${ }^{169}$ Faine v. Brown (Ch. 1750) (unreported), noted in Ramsden v. Hylton, 2 Ves. Sen. 304, 307, 28 Eng. Rep. 196, 198 (Ch. 1751); City of London v. Nash, 3 Atk. 512, 26 Eng. Rep. 1095, 1 Ves. Sen. 12, 27 Eng. Rep. 859 (Ch. 1747); Joynes v. Statham, 3 Atk. 388, 26 Eng. Rep. 1023 (Ch. 1746); Barnardiston v. Lingood, 2 Atk. 133, 26 Eng. Rep. 484 (Ch. 1740).

170 See Nichols v. Gould, 2 Ves. Sen. 422, 28 Eng. Rep. 270 (Ch. 1752); text at note 158 supra.

1712 Atk. 133, 26 Eng. Rep. 484 (Ch. 1740).

172 See Chesterfield v. Janssen, 1 Atk. 301, 305, 26 Eng. Rep. 191, 194-95 (Ch. 1750).

173 Atk. 383, 26 Eng. Rep. 1020 (Ch. 1746). 
kind ought to be certain, fair and just in all its parts." ${ }^{174}$ But he based his holding on misrepresentation, not on inadequacy of consideration. The first unambiguous decision I know of refusing specific performance on grounds of inadequacy of consideration is Underwood v. Hitchcox ${ }^{175}$ (1749), but it is very inadequately reported.

Subsequent decisions, to the time of Lord Eldon, are consistent in reasoning with Lord Hardwicke's approach, ${ }^{176}$ but they do not rest on the single ground of mere inadequacy. Thus, in Gwynne $v$. Heaton $^{177}$ (1778), which goes farther than most, Lord Thurlow said there must be "an inequality so strong, gross, and manifest" that no man of ordinary common sense would consider making such a bargain; ${ }^{178}$ finding such inequality in the facts before him, he set aside the deeds at issue. Ten years later, in Day v. Newman, ${ }^{179}$ Ardern, M.R., (Lord Alvaney) refused, on the ground of inadequacy of price, to enforce an executory contract because the inadequacy was "so enormous, that all mankind must at the first mention of it concur in thinking it so."180 Although he suggested that the court would have acted as it did even if the inadequacy had been less egregious, the doctrine on which the courts relied in the few cases, from the middle of the eighteenth century on, refusing specific performance on grounds of inadequacy alone was far less wide than Horwitz's formulation. ${ }^{181}$

Further, while refusal of specific performance may have left the plaintiff without adequate remedies as a practical matter, eighteenth-century courts did not set aside contracts on grounds of

174 Id. at 386, 26 Eng. Rep. at 1022.

1751 Ves. Sen. 279, 26 Eng. Rep. 1031 (Ch. 1749).

17 Heathcote v. Paignon, 2 Bro. C.C. 167, 29 Eng. Rep. 96 (Ch. 1787); Griffith v. Spratley, 1 Cox 383, 29 Eng. Rep. 1213 (Ch. 1787) (Eyre, L.C.B.), noted in Heathcote v. Paignon, 2 Bro. C.C. at 179 n.4, 29 Eng. Rep. at 102 n.4; Gwynne v. Heaton, 1 Bro. C.C. 1, 28 Eng. Rep. 949 (Ch. 1778) (Thurlow, L.C.); How v. Weldon \& Edwards, 2 Ves. Sen. 516, 28 Eng. Rep. 330 (Ch. 1754) (Sir Thos. Clarke, M.R.).

1771 Bro. C.C. 1 , 28 Eng. Rep. 949 (Ch. 1778).

${ }^{178}$ Id. at 9, 28 Eng. Rep. at 953.

172 Cox 77, 30 Eng. Rep. 36 (Ch. 1788).

${ }^{180} \mathrm{Id}$. at 82,30 Eng. Rep. at 38 . The defendant had agreed, at age 24 , to pay $£ 6,000$ immediately, and $£ 14,000$ when his uncle died, for an estate valued at $£ 9,000$.

18t See text at note 151 supra. The doctrine followed by the courts may also have been limited to inadequacy of price only, as was the civil law doctrine: the adjective "enormous" may echo the civil law's laesio enormis. On the civil law doctrine, see text at notes 27-29 supra. In England, such a doctrine may have been connected with a general belief in the desirability of protecting the landed interest from loss of land at inadequate prices, particularly when youth was involved. The rationale for some of the decisions may be the idea that the contracting party has not acted freely or that he lacks full capacity to contract; the boundary between these ideas is not distinct. 
inequality or inadequacy of consideration alone. Counsel arguing for the refusal of specific performance naturally searched for cases in which contracts had actually been avoided for inequality, from which they could argue a fortiori. The South Sea Bubble cases did not help here, since deposits were forfeited and not returned. The favorite contender was Herne $v$. Meeres ${ }^{182}$ (1687), but it actually involved a fraud on creditors who were suing the purchaser of their debtor's estate. The case did not depend on the parties' power to avoid the contract for inequality. There appears to be no recorded instance of the exercise of such a power. Although it is conceivable that isolated instances might be found in unpublished sources, this alone would not support Horwitz's claim for the existence of a "wellestablished doctrine."

Horwitz's contention that Powell and text writers after him attacked the eighteenth-century doctrine of inadequacy is, if true, an argument for the existence of such a doctrine. I shall argue, however, in the next section of this article, that Powell was not, as Horwitz supposes, an enemy of the idea that contracts marked by great inequality should not be specifically enforced, and perhaps should be set aside. When Powell states that no court has yet refused specific performance for mere inequality, he is only reporting. ${ }^{183}$ Apparently, he did not know of the few cases that can be read as refusing specific performance on grounds of inadequacy alone, in particular Underwood $v$. Hitchcox ${ }^{184}$ (1749), although it had been in print since 1765, and Day $v$. Newman ${ }^{185}$ (1788-but not published until 1816). How he missed these cases, I do not know-it was not, however, out of lack of sympathy with their conclusions, because he clearly favored interfering with sharp bargains. ${ }^{186}$ Perhaps his error influenced courts to take a narrower view of their right to refuse specific performance than they might have taken had he used his opportunity to develop further the doctrine of cases like Underwood. On the other hand, Powell was apparently the first to state clearly the evidentiary theory of inadequacy, that inadequacy creates a strong presumption of fraud. ${ }^{187}$ Powell's writings, therefore, are neither evidence of a well-established doctrine of substantive inadequacy in the eighteenth century nor an attack on such a doctrine or its underlying values.

1821 Vern. 465 (Ch. 1687).

183 See text and notes at notes 353-367 infra.

it 1 Ves. Sen. 279, 26 Eng. Rep. 1031 (Ch. 1788).

iss 2 Cox 77, 30 Eng. Rep. 36 (Ch. 1788).

${ }_{186}$ See text at notes 363-367 infra.

${ }^{187}$ See 2 J. PoweL, supra note 50, at 157-58. 
2. American Cases after 1790. The cases on which Horwitz relies as evidence for his claim that American courts in the eighteenth century interfered with contracts on grounds of inadequacy of consideration all date from after $1790,{ }^{188}$ that is, from the period when, according to Horwitz, courts were abandoning the doctrine. In the first reported American case dealing with the subject, Clitherall v. Ogilvie ${ }^{189}$ (South Carolina 1792), the court refused specific performance. ${ }^{190}$ The decision is not easy to interpret. After pointing out that most of the cases cited by counsel were not directly relevant, 191 the court stated as "a settled rule of this court" that an agreement would not be specifically enforced unless it was "fair, certain, just, equal in all its parts, and for adequate consideration." 102 This was dictum, of course, but that is not the important point. There is good reason to believe that the court was not stating a settled rule in South Carolina, but merely adopting what it thought was the rule in England.

The language quoted above reads suspiciously like Powell's "fair, just, reasonable, bona fide, certain, in all its parts, mutual, useful, made upon a good or valuable consideration." 193 Counsel's version is "fair, certain and just in all its parts," 194 supported by a reference to Buxton v. Lister ${ }^{195}$ (1746). The reference is to this passage in Buxton: "Nothing is more established in this court, than that every agreement of this kind ought to be certain, fair, and just in all its parts." 188 Powell also cites this passage, ${ }^{197}$ but as authority for refusing specific performance on grounds of misrepresentation. Furthermore, neither the court nor counsel in Clitherall made any explicit reference to earlier practice in South Carolina: all the authorities referred to are English. ${ }^{198}$ And in Desaussure's long note to the case, written some years later, "the court" is, oddly enough, a

iss See Horwitz, supra note 1, at 923.

1591 S.C. Eq. (1 Des.) 250 (1792).

10 Id. at 256, 262. Counsel expressly relied on Underwood for the proposition that gross inadequacy was a ground for refusing specific performance. Id. at 256.

iII Id. at $250,257$.

112 Id. at 257-58.

132 J. PowelL, supra note 50, at 221.

i' 1 S.C. Eq. (1 Des.) 250, 256 (1792).

1053 Atk. 383, 26 Eng. Rep. 1020 (Ch. 1746).

11 Id. at 386, 26 Eng. Rep. at 1022.

1972 J. POWELL, supra note 50, at 222.

188 The court relied on Powell and seems to have used him extensively, but it also cited Underwood v. Hitchcox, 1 Ves. Sen. 279, 27 Eng. Rep. 1031 (Ch. 1749) and Gwynne v. Heaton, 1 Bro. C.C. 1, 28 Eng. Rep. 949 (Ch. 1778), neither of which is mentioned in Powell. 
reference to the English Court of Chancery; ${ }^{199}$ the opinion itself uses the term similarly. The case suggests a reception in 1792 of the rule believed to have been adopted in the English Court of Chancery. It does not provide convincing evidence that the same rule represented the received doctrine in South Carolina earlier in the eighteenth century.

Only one other case appears to be directly relevant to the question of relief for inadequacy (or for hardship) in America in the eighteenth century. In Ward $v$. Webber ${ }^{200}$ (Virginia 1794), the defendant argued, on the ground of hardship, that a conveyance of plantations, furniture, and slaves by his late father to his sister, which the father had subsequently cancelled surreptitiously, should not be enforced by equity. ${ }^{201}$ In rejecting this argument, President Pendleton stated:

[I]t is true that the court will never decree iniquity, and there are instances, where they have refused to decree hard bargains though fair, but these are rare, and are generally cases of glaring hardship. For in general, the court will not undertake to estimate the speculations of parties, in a contract, but will deem them the best judges of their own views, and will compel a performance, though they may be eventually disappointed in their expectations. ${ }^{202}$

This passage again shows a general reluctance to interfere with contracts except in extraordinary circumstances, rather than an established doctrine or a long-standing readiness to interfere on equitable grounds.

After 1800 a change is discernible, though not quite the one Horwitz describes. Although courts reduced, or at least failed to develop, the scope of substantive notions of inadequacy, they also laid the basis for continued interference with sharp bargains by adopting a clearer evidentiary theory of inadequacy. Horwitz overlooks that the evidentiary theory in some respects expanded the power of courts to interfere with unequal bargains; this is all the more important because the scope of the substantive theory had been limited to exceptional cases. The change may go back to a

199 I S.C. Eq. (1 Des.) 250, 258 n.* (1792). Apart from Domat and Justinian, all the authorities mentioned are English. Desaussure apparently wrote this note between the publication of 11 Ves. Jun. and of 1 Des. in 1817.

2001 Va. (1 Wash.) 274 (1794).

${ }^{201}$ The principal arguments in the case were that the conveyance had been executed to avoid the possibility of forfeiture for felony and that it was subject to a secret trust. Id.

${ }^{202} \mathrm{Id}$. at 279. 
number of observations by Lord EIdon in English Chancery cases. ${ }^{203}$ The most important was Coles v. Trecothick ${ }^{204}$ (1804). In Coles, having said that the cases dealing with sales of expectancies by heirs "go on very different principles," Lord Eldon continued: "But, farther, unless the inadequacy of price is such as shocks the conscience, and amounts in itself to conclusive and decisive evidence of fraud in the transaction, it is not itself a sufficient ground for refusing a specific performance." 205

This evidentiary theory of inadequacy, which may be derived ultimately from Powell, who stated it in similar terms, ${ }^{206}$ does not appear to involve any change of view from the cases following Lord Hardwicke regarding the degree of inadequacy required. ${ }^{207}$ What does change is the theoretical ground upon which inadequacy operates-as evidence of fraud, not as an independent, substantive ground, and not as constituting "hardship." This can be seen as cutting back on the eighteenth-century cases. A consequence of this reformulation, however, was the invalidation of any distinction between the grounds for refusing specific performance of executory contracts and for rescinding executed contracts, for it was settled that fraud applied indifferently in both contexts.

In England, Lord Eldon's position became settled doctrine, although Fry pointed out difficulties with it. ${ }^{208}$ In America, Desaussure accepted the idea that, as furnishing "violent presumptive evidence of fraud, imposition, or oppression in the buyer; or weakness, ignorance, or deep necessity in the seller," ${ }^{209}$ inadequacy might actually invalidate a contract. He hinted at the notion that specific performance might be refused through inadequacy (though not for inadequacy) even in cases in which the contract was not invalid. ${ }^{210}$ If anything, this use of inadequacy as an evidentiary notion in-

${ }^{203}$ See Lowther v. Lowther, 13 Ves. Jun. 95, 103, 33 Eng. Rep 230, 233 (Ch. 1806) (Erskine, L.C.); Burrowes v. Lock, 10 Ves. Jun. 470, 474-75, 32 Eng. Rep. 927, 929 (Ch. 1805) (Grant, M.R.); Mortlock v. Buller, 10 Ves. Jun. 292, 305, 314, 32 Eng. Rep. 857, 862, 865 (Ch. 1804); Emery v. Wase, 8 Ves. Jun. 505, 517, 32 Eng. Rep. 451, 455 (Ch. 1803); Low v. Barchard, 8 Ves. Jun. 133, 137, 32 Eng. Rep. 303, 304 (Ch. 1803); White v. Damon, 7 Ves. Jun. 30, 32 Eng. Rep. 13 (Ch. 1802). In Stilwell v. Wilkins, Jac. 280, 37 Eng. Rep. 857 (Ch. 1821), Eldon was still indecisive on the issue.

2os 9 Ves. Jun. 234, 32 Eng. Rep. 592 (Ch. 1804).

20s Id. at 246, 32 Eng. Rep. at 597. A similar doctrine is stated in Low v. Barchard, 8 Ves. Jun. 133, 32 Eng. Rep. 303 (Ch. 1803).

2062 J. Powell, supra note 50 at $78,157-58$. See text at note 363 infra.

207 See text at note 180 supra.

208 E. Fry, A Treatise on the Specific Performance of Contracts $\S \S 279-282$, at 128-31 (London 1858).

2001 S.C. Eq. (1 Des.) at 258 n.*. See note 199 supra.

2101 S.C. Eq. (1 Des.) at 258 n.*. 
creased the significance of inadequacy of price, for I have been unable to find an instance in the eighteenth century in which a court set aside a contract, rather than merely refusing to order specific performance, either for inadequacy per se or for inadequacy as conclusive evidence of fraud.

The American cases, however, continued to state the law as before, perhaps a little more restrictively for a few years. In Gregor v. Duncan ${ }^{211}$ (1808), Chancellor Rutledge, who had been a member of the court that decided Clitherall $v$. Ogilvie, ${ }^{212}$ now claimed that it was "generally agreed" that neither executory nor executed contracts could be set aside for "mere inadequacy of price" in the absence of fraud or some additional factor. ${ }^{213}$ In the context, he apparently intended the same principle to apply to refusal of specific performance. In Campbell v. Spencer ${ }^{214}$ (1809), a Pennsylvania case involving an appeal from a decision by the trial judge setting aside a jury verdict for the defendant in an action for ejectment, the judges sympathized with the defendant. ${ }^{215}$ They said that as chancellors they might not have granted specific performance, intimating that in equity specific performance might properly be refused in cases in which inadequacy of price combined with other factors. ${ }^{216}$ At the same time, they stressed that the law supported the plaintiff. They ultimately reinstated the jury verdict in favor of the defendant on the ground that jury verdicts should not be set aside unless they are unquestionably wrong. In Bunch v. Hurst ${ }^{217}$ (1811), the court did set aside a contract in which the price was enormously inadequate, but the outwitted party was a near idiot.

Butler v. Haskell ${ }^{218}$ (1816) is the first American decision clearly influenced by Lord Eldon's reformulation of the doctrine. There,

2112 S.C. Eq. (2 Des.) 636 (1808). Desaussure described this as "a very important case," but explained that he could not obtain much information about it. Id. at 636-37. He gave a slightly different account of the case in his opinion in Butler v. Haskell, 4 S.C. Eq. (4 Des.) 651, 696 (1816), presumably from his notes. Gregor $v$. Duncan does not on its face indicate any English influence, but given the state of these reports, it is impossible to tell.

2121 S.C. Eq. (1 Des.) 250 (1792).

2132 S.C. Eq. (2 Des.) 636, 639 (1808).

2142 Binn. 129 (Pa. 1809).

215 Tilgham, C.J., said:

[T] here are circumstances in this transaction, which I do not like. I do not like the sending for a man to a tavern, and bargaining for the land which supported his family, amidst the drinking of bitters early in the morning; and I do not like a contract by which a farmer is involved in the folly of buying a store of goods.

Id. at 133.

216 Id. at 133, 135.

${ }_{217}$ Noted in Butler v. Haskell, 4 S.C. Eq. (4 Des.) 651, 697 (1816).

2184 S.C. Eq. (4 Des.) 651 (1816). 
after elaborate argument and consideration of both English and American authorities, the South Carolina court of equity appeals set aside an executed contract. At first instance, Chancellor Thompson had refused relief: inadequacy, he had said, in the absence of fraud or some other ground, was not a sufficient basis in America for either rescinding an executed contract or refusing specific performance. ${ }^{219}$ Desaussure, now on the bench, delivered the opinion reversing the Chancellor, stating this principle:

[W] hereever [sic] the court perceives that a sale of property has been made at a grossly inadequate price, such as would shock a correct mind, this inadequacy furnishes a strong, and in general a conclusive, presumption, though there be no direct proof of fraud, that an undue advantage has been taken of the ignorance, the weakness, or the distress and necessity of the vendor: and this imposes on the purchaser a necessity to remove this violent presumption by the clearest evidence of the fairness of his conduct; and the relief is given by the court, either by refusing to enforce the contract, or by setting it aside altogether, according to the circumstances of the case. ${ }^{220}$

Again, however, as in most of the eighteenth-century cases, there was more than mere inadequacy in Butler. Desaussure mentioned the illiteracy and inexperience of the sellers and that the buyerdefendant had been their agent, although the opinion did not rest on these grounds. 221

The next leading case is Seymour v. Delancy ${ }^{222}$ (1824), in New York. Again, both majority and minority fully considered the English and American authorities. The opinion of the minority, elaborately argued by Savage, C.J., ${ }^{223}$ was that specific performance might be refused on the ground of inadequacy alone. To set aside a contract once executed, however, the inadequacy must be so gross

219 Id. at 675 . He was extremely hostile to the idea:

This principle [relief for inadequacy], although familiar in the English courts, is somewhat novel in this country. The most of the cases there under this head, arise from young heirs selling their expectancy, and the policy of that country seems to require that there should be one great and influential man in a family, to the impoverishment and disinheritance of the others. A similar policy does not prevail here, nor do I think the doctrine should be carried to so great an extent.

220 Id. at 697.

221 Id. at $682-84,698$.

${ }^{222} 3$ Cow. 445 (N.Y. 1824). This case was reported in the lower court as Seymour v. Delancey, 6 Johns. Ch. 222 (N.Y. Ch. 1822).

${ }^{223} 3$ Cow. 504-22. Nine Senators concurred in the minority opinion, which upheld the view of Chancellor Kent at first instance. See Seymour v. Delancey, 6 Johns. Ch. 222 (N.Y. Ch. 1822). Kent had distinguished the contrary view of Lord Eldon on the ground that Eldon was only considering sales at auction. Id. at 229. 
as to amount to fraud under the evidentiary theory, which Savage conceived to be restrictive in character. ${ }^{224}$ Here, Savage said, the contract. was executory and specific performance should be refused. The majority view, expressed by Senator John Sudam, ${ }^{225}$ was that specific performance would be refused only "where the inadequacy of price . . . amounts to conclusive evidence of fraud." 226 The evidentiary theory, he said, applied both to executory and executed contracts (as Lord Eldon had suggested), and on the facts Sudam found the inadequacy was not gross enough to constitute conclusive evidence of fraud. ${ }^{227}$

Many of the differences between Horwitz's understanding of the significance of inadequacy of consideration and mine are reflected in the way we understand Seymour. For Horwitz, the case marks the crucial event in an epochal struggle: "The underlying logic of the attack on a substantive doctrine of consideration came to fruition in America with the great New York case of Seymour $v$. Delancy. ${ }^{2228}$ I take a less dramatic view of the case. The split in the court, it seems to me, may have depended less on the different theories argued by the majority and the minority than on their different estimation of the facts. The issue, ultimately, was whether this particular inadequacy was gross enough to justify interference with the contract. Chancellor Kent had argued that, even if inadequacy alone was not enough in this case to justify such interference, it was very great and, in addition, there were other grounds for refusing specific performance. ${ }^{229}$ Senator Sudam, on the other hand, asserted that the contract was fair and reasonable on every count except adequacy of price, and it was not clear to him that the price had been inadequate at the time the contract was made. ${ }^{230}$

Seymour v. Delancy does not introduce a new principle to

224 3 Cow. 445, 516-18 (N.Y. 1824).

225 Id. at 522-36. Thirteen Senators concurred.

226 Id. at 529 .

222 Id. at 531.

${ }_{223}$ Horwitz, supra note 1 , at 944 .

223 The defendants had inherited two farms from Thomas Ellison, who had contracted to exchange them with the plaintiff for some village lots. Kent suggested that Ellison was an alcoholic who had not been competent to enter into an enforceable bargain. 6 Johns. Ch. at 232. Kent also stated that specific performance could be refused because the plaintiff had, as it turned out, not been ready to go forward at the date set for the exchange. Id. at 233. Finally Kent found the price very inadequate, for he determined the farms to be worth at least $\$ 12,000$ and the village lots at most $\$ 6,000$. Id. at 224,232 .

${ }^{230}$ Senator Sudam emphasized the reasonable if speculative nature of the transaction, 3 Cow. at 528-29, and stressed that the difference between the average of six valuations of the farmland and the lots was relatively small $-\$ 12,686$ to $\$ 10,856$. Id. at $530-31$. 
America. The evidentiary theory of inadequacy had been accepted, and the substantive theory rejected (at least sub silentio), in Butler $v$. Haskell, ${ }^{231}$ by the same Desaussure whom Horwitz treats as an exponent of the older, better "eighteenth-century theory."232 $\mathrm{Al}$ though Seymour was an influential case, the precise significance of inadequacy continued to provoke argument after it. As late as 1831, in Rodman v. Zilley, ${ }^{233}$ Kent's minority view in Seymour was cited in dictum as authority for refusing specific performance in the case of an inequitable transaction. Above all, Horwitz's interpretation of Seymour $v$. Delancy is incompatible with the view argued in this section that inadequacy of consideration was a much narrower and less frequently applied doctrine in the eighteenth century than Horwitz claims, and that the shift to an evidentiary theory of inadequacy did not require abandoning equitable notions, since it allowed the courts to continue, although on a different doctrinal basis, to interfere with bargains they found outrageous.

\section{Damages at Law and the Substantive Doctrine of Considera- tion}

For Horwitz, Seymour v. Delancy ${ }^{234}$ represents the defeat not only of the idea that equity should refuse to decree specific performance for inadequacy of consideration but of the underlying belief that all courts, of law as well as equity, have the right and the duty to supervise the fairness of contracts. ${ }^{235}$ With respect to courts of law, this belief allegedly took the form of a "substantive doctrine of consideration which allowed the jury to take into account not only whether there was consideration, but also whether it was adequate, before awarding damages." 236

Horwitz admits there is "no direct evidence of a substantive doctrine of consideration in eighteenth century England;"'237 unfortunately, his indirect evidence that this doctrine existed in English law is minimal. Because Richard Wooddeson in his Vinerian lectures in $\mathrm{Oxford}^{238}$ said there was an implied warranty of merchanta-

2314 S.C. Eq. (4 Des.) 651, 686-8, 692, 697. (1816). Desaussure rejected the substantive theory more clearly in his note published in 1817 to Clitherall v. Ogilvie, 1 S.C. Eq. (1 Des.)

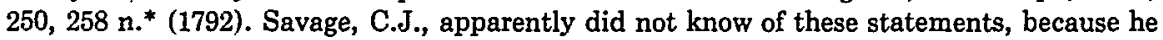
placed Desaussure with those disagreeing with Eldon. 3 Cow. 445, 517 (N.Y. 1824).

232 Horwitz, supra note 1 , at 923 .

2231 N.J. Eq. 320 (1831).

as Id. at 324-25.

${ }_{235}$ Horwitz, supra note 1 , at 924 .

25. Id.

207 Id. at 926.

$2 * 2$ R. Wooddeson, A Systematical View of the Laws of England 415 (Dublin 1792).

These lectures were first delivered earlier, beginning in 1777 . 
bility when a sound price was given, Horwitz asserts, "one may conclude that in both England and America, when the selling price was greater than the supposed objective value of the thing bought, juries were permitted to reduce the damages in an action by the seller."239 This, of course, in no way follows. It is one thing to impose liability by way of implied warranty on a seller who delivers a defective or unmerchantable thing; it is another to reduce the buyer's indebtedness to the seller, or the seller's damages for a refusal to accept delivery, because the price agreed is higher than "the objective value," whatever this expression is taken to mean. So far as I am aware, there is no evidence whatsoever that such a doctrine ever existed in England. Horwitz produces nothing except this bold non sequitur. ${ }^{240}$

It is true that jury awards were largely uncontrolled in the eighteenth century. For all one knows, or may ever know, juries may sometimes have reduced the sum recovered when the price appeared exorbitant, or for that matter when they thought the plaintiff's girth exorbitant. Horwitz relies ${ }^{241}$ upon a statement by Chancellor Kent in Seymour $v$. Delancey"242 (1822) that "relief can be afforded [by a jury] in damages, with a moderation agreeable to equity and good conscience, and ... the claims and pretensions of each party can be duly attended to, and be admitted to govern the assessment."243 Chancellor Kent's argument here was designed to show that the existence of jury discretion makes equitable interference with contracts less necessary. In particular, he was supporting his refusal to decree specific performance in Seymour by pointing out that an action at law may have a more equitable outcome, because of jury discretion, than a suit for specific performance in equity, for the Chancellor normally must choose between giving the plaintiff all or nothing. This sort of analysis, however, is not the application of a "substantive doctrine of consideration" or of any legal doctrine other than that the assessment of damages was at the discretion of the jury.

It is misconceived in principle to confuse legally unregulated

${ }^{239}$ Horwitz, supra note 1 , at 927.

200 Horwitz refers to the unpublished contract treatise "Of Contracts," attributed to Gilbert (c. 1720) (Hargrave Ms. 265, British Library) for support, supra note 1, at $926 \mathrm{6}$.53. But even as Horwitz himself presents the matter, the treatise deals with implied warranties of merchantability, not with determining the adequacy of the price irrespective of defects in quality: In any event, for reasons given at note 284 infra, Horwitz's interpretation of this text is incorrect. Parkinson v. Lee, 2 East. 314, 322, 102 Eng. Rep. 389, 392 (K.B. 1802), discussed in notes 289-292 infra, also deals with an implied warranty of merchantability.

2ı1 Horwitz, supra note 1, at 924 .

2426 Johns. Ch. 222 (N.Y. Ch. 1822), rev'd, Seymour v. Delancy, 3 Cow. 445 (N.Y. 1824).

${ }^{243}$ Id. at 232. 
practices, particularly those concerning what were by definition questions of "fact," with legal doctrines. Nor can we be confident, as Horwitz seems to be, that the result of the lack of regulation of the jury was that "the community's sense of fairness was often the dominant standard in contracts cases." 244 We simply do not know: we do not know whether juries allowed their "sense of fairness" to interfere with their understanding of the requirements of the law, and we do not know whether the sense of fairness of a community that tolerated imprisonment for debt and savage punishment for petty crimes against property called for reduced damages when the consideration seemed inadequate. Romanticism about juries is not history.

So far as American law is concerned, Horwitz bases his argument on a number of case reports from Pennsylvania and Massachusetts. I will take his Pennsylvania cases in chronological order. Wharton v. Morris ${ }^{245}$ (1785) hardly seems relevant. A bond was conditioned on the payment of a sum of money (the price for a quantity of tobacco) "in lawful current money of Pennsylvania." 246 There were two practical problems. Pennsylvania had not made any provision regarding the matter of lawful currency; McKeon, C.J., told the jury to interpret the bond as referring to paper money issued under the authority of Congress. Unfortunately, that paper had depreciated. The court therefore instructed the jury either to reduce the penalty to gold or silver according to the scale of depreciation that had overtaken paper money or, if they thought it more equitable, to find a verdict for the value of the tobacco together with interest on this sum from the day on which the price had been payable. This heroic attempt to grapple with a problem of interpretation coupled with the attendant problems of a depreciating currency hardly amounts to a statement of "the substantive doctrine of consideration." Furthermore, as Horwitz himself points out, ${ }^{247}$ because there was no distinct equity jurisdiction in Pennsylvania, equity was administered in the courts of law; the alternative offered to the jury here was simply an attempt to apply the orthodox equitable principle of relief from penalties. Nobody even suggested that the tobacco was not sold for its "objective value."

Hollingsworth $v$. Ogle ${ }^{248}(1788)$ is another Pennsylvania case

21s Horwitz, supra note 1, at 925.

215 1 Dall. 124 (Pa. 1785).

218 Id. at 124.

217 Horwitz, supra note 1, at 924, 926.

213 1 Dall. 257 (Pa. 1788). 
dominated by the unusual problems created by a rapidly depreciating currency. In' 1779 , when Continental paper "was worth no more than at the rate of twenty Continental dollars for one in specie," the defendants borrowed $£ 500$ of Continental paper. They promised to repay" "the full and just sum of $£ 100$ hard money or specie" " in five years, with " "lawful interest" "250 - or four times as much as they had borrowed in hard money equivalent. This was apparently a speculative contract: if Continental paper appreciated to over 20 percent of its face value, the debtor would make a profit. But the paper continued to fall. The defendants gave the plaintiff a bond of $£ 200$ hard money or specie in consideration for this loan. When the plaintiff brought an action of debt on the bond, they pleaded performance-they claimed to have repaid what they owed. A recent Pennsylvania statute had declared that, of debts incurred after January 1,1777 , creditors could recover only as much as they had lent in real value. Under this statute, defendants apparently owed only $£ 25$ hard money or specie, not $£ 100$. But this did not answer whether all they had to pay to avoid the $£ 200$ penalty was $£ 25$, for the bond expressly called for a payment of $£ 100$. The court said that it had no answer to this question. "Since, therefore, we have no rule to guide us, but the exercise of a legal discretion, it may be proper to reflect, that it will be as inconsistent with equity to give too little, as to give too much." ${ }^{251}$ With this somewhat hazy guidance, the jury was told to presume (that is, to pretend), in adjudicating the plea

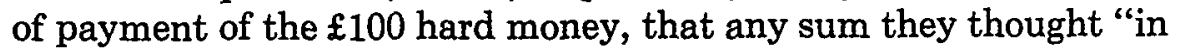
equity and good conscience" ought not to be payable had in fact been paid.252 The decision has nothing to do with the problem of adequacy of consideration, much less with any legal "substantive doctrine of consideration."

Horwitz's next two cases seem quite irrelevant. Conrad $v$. Conrad $^{253}$ (1793) involved a promise by a father to his illegitimate son to give him 100 acres of a 260 -acre plantation if he stayed at home to work it, which would have given a greater share to him than to his four legitimate brothers. The court admitted evidence that the father had intended to give the illegitimate son an equal share of only 52 acres. The case is not relevant to inadequacy of considera-

299 Id. at 258 .

250 Id. at 257.

251 Id. at 260.

${ }^{252}$ Id. Horwitz reports this instruction, without any account of the case, as if it were a customary instruction to juries in actions on bonds. Horwitz, supra note 1, at 924 .

253 Dall. 130 (Pa. 1793). 
tion. In Gilchreest v. Pollock ${ }^{254}$ (1795), the plaintiff had sold some stock to be delivered in the future and had taken a promissory note in return. The buyer subsequently refused to accept delivery, and neither he nor his guarantor would make good on the note. The action was brought against the guarantor. In the passage relied upon by Horwitz, ${ }^{255}$ counsel for the guarantor (so far as one can tell from the abbreviated notes of his argument) was maintaining that speculative contracts of this character are harmful and that the court should therefore not be anxious to favor them ${ }^{256} \mathrm{He}$ was also arguing that there should be mutuality in an executory contract, and that it was lacking in this case. In this context he asserted: "Contracts of this nature tend to discourage industry. The claim of the plaintiff should be both legal and equitable before he can call on a jury to execute the agreement. The remedy on both sides should be mutual." 257 The second sentence can mean almost anything; the reduction of damages for inadequacy of consideration is nowhere so much as mentioned. 258

In the last Pennsylvania case in this group, Armstrong $v$. $M c G h e e^{259}$ (1795), the court rejected counsel's argument that inadequacy of consideration was a ground not merely for reducing damages but for setting aside the contract. There was some plausibility in counsel's astonishing argument, for there was evidence suggesting that the sale in question had been a joke. Armstrong was annoyed with his valuable horse because it seemed jaded and lame after a ride. He offered, in front of several people, to sell it for a trifling sum. His acquaintance McGhee accepted the "offer," and Armstrong let him have the horse. Later, Armstrong asked to have the horse back, but McGhee refused to return it, and held him to the agreement. Armstrong maintained that he had not intended the offer seriously, but the court refused to go behind the words uttered and also rejected the argument from inadequacy of consideration. ${ }^{261}$ There is no evidence that the parties argued a power to reduce

242 Yeates $18(\mathrm{~Pa} .1795)$.

25 Horwitz, supra note 1, at 924 n. 40.

zo Gilchreest v. Pollock, 2 Yeates 18, 19 (Pa. 1795) (argument of counsel).

257 Id.

27* Horwitz provides no other evidence for his assertion that "Pennsylvania lawyers often argued that a plaintiff's claim on a contract 'should be both legal and equitable before he can call on a jury to execute the agreement," "Horwitz, supra note 1, at 924 (quoting Gilchreest v. Pollock, 2 Yeates 18,19 (Pa. 1795) (argument of counsel)).

207 Addis. 261 (Pa. C.P. 1795).

${ }^{260}$ The case went to the jury, which could not agree on a verdict. In a second trial, Armstrong got damages of $£ 8-$ but still not the return of the horse. Id. at 262 . 
damages in this case. ${ }^{261}$

With respect to the early Massachusetts cases, Horwitz writes that in Pynchon v. Brewster"262 (1766), "Chief Justice Hutchinson instructed the jury in an action for a fixed price that they 'might ... if they thought it reasonable, lessen the Charges in the [plaintiff's] Account.' ', ${ }_{263}$ This statement of the case is, to say the least, misleading. The crucial issue in the case revolved around the contract's lack of a fixed price. The plaintiff, a doctor, brought indebitatus assumpsit on a bill submitted for medicines, travel, and attendance. Defendant had made no express promise or promises to pay a particular sum or sums. The point at issue was whether indebitatus assumpsit was appropriate on the basis of a promise, implied from the circumstances, to pay the customary prices and fees $^{264}$ or whether the proper form of action was quantum meruit. If indebitatus assumpsit did lie, the court also had to decide whether the jury could choose to reduce the sum recoverable if the claim appeared excessive (that is, act as if the action was brought on a quantum meruit) or whether in this form of action it had to award either the whole amount claimed by the plaintiff or nothing at all. ${ }^{265}$ The court held that indebitatus assumpsit could be used, but that the jury was not bound to choose between awarding either the whole sum claimed or nothing. ${ }^{266}$ The decision was apparently soon reversed. ${ }^{267}$ The case has nothing to do with any interference with an express contract on the ground of inadequacy, or with reduction of

261 Counsel did, however, refer to the barleycorn case, James v. Morgan, 1 Lev. 111, 83 Eng. Rep. 323 (K.B. 1663), in his argument for setting aside the contract. Addis. 261, 261 (Pa. C.P. 1795).

262 Quincy 224 (Mass. 1766).

${ }^{263}$ Horwitz, supra note 1, at 925 (quoting Pynchon v. Brewster, Quincy 224, 225 (Mass. 1766) (emphasis deleted by Horwitz)). Horwitz discusses the case more fully in id. at 935.

261 Hutchinson justified allowing indebitatus assumpsit to lie (distinguishing Tyler v. Richards, Quincy 195 (Mass. 1765), where it had not been allowed to lie for boarding and schooling the defendant's son) on the ground that "Travel for Physicians, their Drugs and Attendance, had as a fixed a Price as Goods sold by a Shopkeeper." Pynchon v. Brewster, Quincy 224, 224 (Mass. 1766).

${ }^{265}$ The reporter notes that the former rule in indebitatus assumpsit (as in debt) was that only the precise sum was recoverable. Id. at 226. Evidence showing a different sum due would lead to a nonsuit for variance. The quantum meruit and quantum valebant counts evolved in order to obviate this doctrine; hence when the doctrine was abandoned in the eighteenth century, these forms of action were abandoned as well. The precise chronology of the change is uncertain, but see Thompson v. Spencer (1768), noted in F. BuLLER, AN INTroduction to the Law Relative to Trials at Nisi Prius 129 (2d ed. London 1775) (1st ed. London 1772). See also text and notes at notes 322-326 infra.

${ }_{268}$ Pynchon v. Brewster, Quincy 224, 224-25 (Mass. 1766).

${ }^{267}$ The reporter notes that "[ $[t]$ he Resolution in this Case was denied to be Law by the whole Court, Ch. Just. absente, in the Case of Letestu \& Glover, August Term, 1770." Id. at 225. 
damages on that account; it merely allows the jury to settle reasonable remuneration in both forms of action where the parties had not agreed on a specific price.

Horwitz follows his quotation from Pynchon v. Brewster with another statement of Hutchinson's, from Noble v. Smith ${ }^{268}$ (1767): "It seems hard that an Inquiring into the Consideration should be denied, and that Evidence should be refused in Diminution of Damages."268 Although Hutchinson voted with the majority to exclude evidence of inadequacy in this dispute over a promissory note, Horwitz maintains that "the court treated notes as an exception to the general rule governing contracts" and that Hutchinson's remark "does acknowledge the general rule." 270 In fact, the case never mentions a general rule for contracts, nor does it conclude that notes should be treated differently from other contracts. Hutchinson merely states the main policy arguments for and against an inquiry into consideration in the case of promissory notes:

On the one Hand, a Note to a considerable Amount may be obtained upon a very trifling Consideration: It seems hard that an Inquiry into the Consideration should be denied ..... On the other Hand, People, upon a Settlement of Accounts, or Matters in Dispute, think themselves quite safe in taking a Note for the Sum due, and reasonably suppose all Necessity of keeping the Evidence of the Consideration at an End; it would be big with Mischief to oblige People to stand always prepared to contest Evidence that might be offered to the Sufficiency of the Consideration. ${ }^{271}$

Hutchinson concludes that it would be better not to admit "such Examinations into the Consideration of Notes" 272 without ever mentioning whether such inquiry should be allowed in other contracts, or what should be the scope of such inquiry if it were allowed.

Horwitz further relies ${ }^{273}$ on passages in John Adams's student notes $^{274}$ (circa 1759), but these merely state what was quite orthodox law: that a "sufficient Consideration" was essential in a declaration

24x Quincy 254 (Mass. 1767).

23. Id. at 255, quoted in Horwitz, supra note 1, at 925 .

230 Horwitz, supra note 1, at 925 n.46. Horwitz might have been misled by the reporter's note to Noble v. Smith, Quincy 254, 255 (Mass. 1767) that "[t]he opposite doctrine has long [before 1865] been established." The reporter meant long before 1865, when his report was published; he referred to an opinion by Chief Justice Shaw, who became Chief Justice in 1831.

231 Id. at 255.

272 Id.

273 Horwitz, supra note 1 , at $924 \&$ n.42.

2741 Legal Papers of John AdAMS, supra note 72, at 9, 12, 15. 
and that "[n]o Consideration, or an insufficient Consideration" was a good ground for a motion in arrest of judgment or a writ of error. ${ }^{275}$ The point was partly substantive. It had been established since the sixteenth century that it was essential to aver consideration in a declaration, and that the consideration had to be sufficient. ${ }^{276}$ This meant that, with some exceptions, a declaration containing no averment was defective and that the consideration had to be legally acceptable-for example, natural love and affection were insufficient. The point was also partly procedural. Objection could be taken to the absence of an appropriate averment by a motion in arrest of judgment or by writ of error, because the defect caused by absence or insufficiency of consideration in a declaration was not cured by the verdict if it had not been raised at an earlier stage in the proceedings. This has nothing to do with any doctrine about adequacy. Indeed, in the paragraph following that from which Horwitz quotes, Adams noted the well-established doctrine that a court will not inquire into adequacy. ${ }^{277}$ All in all, the evidence in favor of a substantive doctrine of consideration in the eighteenth century is very weak.

\section{E. The Sound-Price Doctrine}

The "sound-price doctrine" must be distinguished from the "substantive doctrine of consideration." The question whether a "sound price" gave rise to an implied warranty of quality is quite different from the question whether an "unsound" price allowed the party who was the victim of a sharp deal to mitigate damages or to get out of the bargain altogether. ${ }^{278}$ Evidence of the existence of a "substantive doctrine of consideration" is, as I have tried to show, ${ }^{279}$ almost completely lacking. There is more evidence of the existence of a sound-price doctrine before about 1790, but it is meager, it

${ }^{275}$ Id. at 9.

276 See A. Simpson, supra note 42, at 406-12, 434-37, 449-52.

${ }_{277}$ "If the Consideration, on which a Promise is made, be a Benefit to the Defendant or any Trouble or Prejudice to the Plaintiff, it is sufficient." 1 Legal Papers of John ADaMs, supra note 72, at 9. Horwitz, supra note 1, at 935, also points to Adams's argument in Tyler v. Richards, Quincy 195, 195-96 (Mass. 1765) that indebitatus assumpsit should lie for boarding and schooling because "[ $t$ ]he Price for Boarding and Schooling is as much settled in the Country, as it is in the Town for a Yard of Cloth, or a day's Work by a Carpenter." Horwitz calls this a "remnant of the medieval just price theory of value," reflecting "an economic system often based on customary prices." Horwitz, supra note 1, at 935 . The issue in the case was whether indebitatus assumpsit would lie; Adams lost the case, took the opposite tack the following year in Pynchon v. Brewster, Quincy 224 (Mass. 1766), and lost again.

${ }^{27 x}$ See text at notes $238-240$ supra.

${ }^{279}$ See pp. 573-80 supra. 
comes almost entirely from writers of treatises, not from case law, and it does not allow us to say very much about the nature, scope, or history of the doctrine in the eighteenth century.

Horwitz's evidence ${ }^{280}$ for the sound-price doctrine in eighteenthcentury England is drawn partly from Wooddeson's lectures, ${ }^{281}$ partly from an unpublished treatise on contracts from about $1720,{ }^{282}$ and partly from remarks of Grose, J., in Parkinson v. Lee ${ }^{2 \times 3}$ (1802), The passage that Horwitz partially quotes ${ }^{284}$ from Gilbert's unpublished treatise ${ }^{285}$ (circa 1720) is not easy to interpret, but it certainly has nothing to do with any implication of a warranty from the price paid, nor is it concerned with warranties at all. Gilbert is discussing the relationship between what may be given in evidence to the jury and what must be expressly alleged in the declaration, and in this context he notes two anonymous and otherwise unpublished decisions at the Trinity Assizes at Maidstone in $1700 .{ }^{286} \mathrm{He}$ cites the first for the standard principle that it is no use to establish a good contract in evidence when it is different in substance from what was alleged in the declaration. ${ }^{287}$ The second case, which refines this principle, reads:

But if a man Assumed to pay so much money for Hops, if delivered well pickt dryed \& bagg'd this is good evidence on a Generall Assumpsit because so they ought to be whether Contracted for or not for the party ought to make them Merchantable goods \& see them well delivered without any Special pro-

2xo Horwitz, supra note 1, at 926-27 \& n.53.

2x1 2 R. WOOdDESON, supra note 238 , at 415 . See text at note 238 supra.

$2 \times 2$ "Of Contracts," supra note 240, at f. 94a.

202 East. 314, 102 Eng. Rep. 389 (K.B. 1802). I know of only one other eighteenthcentury English reference to sound price, Powell, who says:

And, in some contracts, the intention of the parties, as to the nature of their assent, will be inferred from circumstances; as from price, or the like. Thus if a man sell a horse for a price, which it could not be worth, unless it were sound, the contract will be void, if it turn out otherwise; for the purchaser would never have consented to give a sound price, unless he were to have a sound horse.

$1 \mathrm{~J}$. Powell, supra note 50 , at 150 . Powell supports this by a general reference to "the writers on natural law" and by the example of a fraudulent sale of a female slave disguised in the clothes of a man "and offered to be hired or sold in that character." Id. The example is irrelevant, however, because Powell's argument is not that an unsound price is evidence of fraud, but that price is evidence of the intention of the parties.

$2 \times 4$ Horwitz, supra note 1, at 926 n.53.

$2 x$ "Of Contracts," supra note 240 , at f. $94 \mathrm{a}$.

2xs I imagine, although I have not confirmed it, that Gilbert, who had been called to the bar two years earlier, attended the assizes and noted the cases himself.

$2 x 7$ "Of Contracts," supra note 240, at f. 93b-94a. 
vision in the Contract tho' there were no more than a generall Sale of the Commodity. ${ }^{288}$

The case holds that the plaintiff may give in evidence the agreement that the hops were to be delivered well picked, dried, and bagged, although this had not been expressly alleged in the declaration. The reason given for this ruling, which was only at nisi prius, does appear to recognize a general obligation on a seller to deliver merchantable goods, but it does not relate this obligation to the price paid. Gilbert does not elsewhere instance any other specific application of the admittedly wide principle stated.

Nor does the case law provide convincing evidence. In Parkinson $v$. Lee ${ }^{289}$ (1802), Grose, J., stated that before Stuart $v$. Wilkins"290 (1778) a sound price given was "tantamount to a warranty of soundness" of the goods, but that in Stuart Lord Mansfield had rejected the sound price doctrine. ${ }^{291}$ Lord Mansfield's opinion, however, did not actually state that there was such a doctrine and that he was rejecting it, so it cannot be evidence for the acceptance of the sound-price doctrine by the courts before 1778 . On the other hand, Lord Mansfield did not reject sound-price notions quite as thoroughly as Grose indicated, so Stuart $v$. Wilkins itself may stand as evidence for the acceptance by English courts, at least late in the eighteenth century, of a mild variant of the sound-price doctrine. Lord Mansfield said that "[s]elling for a sound price without warranty may be a ground for an assumpsit, but, in such a case, it ought to be laid that the defendant knew of the unsoundness." 292 This intermediate view would cover liability for mere failure to disclose a known defect even when there is no misrepresentation or active concealment.

From these meager references it is impossible to form a clear idea of the sound-price doctrine or of its role in eighteenth-century English courts. There is no clear indication that any English court of law ever formally accepted it. The references may mean that some judges did invite juries to find a warranty, or to find that there was no consent, when a sound price was given or agreed upon and the goods were defective. "Sound price," then, appears to be not so much a legal doctrine as an expression used by some judges in

\footnotetext{
${ }^{2 \times x}$ Id. at f. $94 \mathrm{a}$.

$2 \times 9$ East. 314, 102 Eng. Rep. 389 (K.B. 1802).

2901 Dougl. 18, 99 Eng. Rep. 15 (K,B. 1778).

2912 East. at 322, 102 Eng. Rep. at 392.

2921 Dougl. at 20, 99 Eng. Rep. at 16.
} 
directing juries. ${ }^{293}$ The references do not allow us to say much about the scope of the doctrine-that is, what it is judges really told juries. Since an express warranty of quality normally covered all defects, whether or not the seller knew of them, perhaps the same was true if a warranty was implied, but this is surmise. It is not at all clear in what transactions such warranties might be implied, whether a sound price was supposed to protect against patent defects as well as latent ones, or what the relationship was between the view that a sound price implied some sort of warranty of quality and the quite different theory-though it reaches a similar result in many situations - that failure to disclose known latent defects constitutes fraud or, at least, evidence of fraud.

In Mellish v. Motteux ${ }^{294}$ (1792), Lord Kenyon proceeded on the basis that there was a duty of disclosure in a case involving the sale of an unseaworthy ship, with defective futtocks (frame timbers). Parkinson v. Lee ${ }^{285}$ (1802), which held that there was no implied warranty of merchantable quality in a sale of hops by sample at a fair market price, is not inconsistent with Mellish v. Motteux, for it was a case in which the seller had no knowledge of the defect in the hops. Thus, even after Parkinson v. Lee there was a possibility that English common law would recognize a duty of disclosure of known defects by the roundabout mechanism of treating nondisclosure as fraud.

In America, the early history of the sound-price doctrine is very difficult to trace. Only two cases earlier than 1790 seem to be at all relevant. In Waddill v. Chamberlayne ${ }^{298}$ (Virginia 1735), an action on the case in the nature of an action of deceit was brought on the sale of a slave. It was alleged that the seller, who received a high price, knew that the slave was suffering from an incurable disease and was worthless. The plaintiff secured a verdict, but we have in the report an elaborate motion that the reporter himself had introduced to arrest judgment on the ground that no express warranty was alleged or proved. The court rejected this argument, which referred extensively to English authority and to the merits of caveat emptor. But since no reasons for the court's decision were recorded, it is quite impossible to tell whether the sound-price idea lay behind

${ }^{203}$ Blackstone, for example, said that only warranties of good title, not warranties of soundness, are implied by law. $2 \mathrm{~W}$. Blackstone, Commentaries * 451 . Horwitz admits this. Horwitz, supra note 1, at 926 n.53.

as Peake 115, 170 Eng. Rep. 113 (1792) (nisi prius).

$2 * 2$ East. 314, 102 Eng. Rep. 389 (K.B. 1802).

2r Reported in 2 Virginia Colonial Decisions B45 (R. Barton ed. 1909). 
it or whether the court applied the principle that a failure to disclose a known defect was fraudulent. The other early case, Baker $v$. Frobisher $^{297}$ (Massachusetts 1762), also rejected caveat emptor, but apparently on a quite different theory. It held that there was an obligation to see that goods sold, in this case soap, were merchantable. The laconic report does not relate this obligation to the price paid for the goods.

The earliest American cases holding clearly that a sound price gives rise to an implied warranty against all faults were influenced by the treatises. In Timrod $v$. Shoolbred ${ }^{298}$ (1793), a South Carolina case, the source is Powell. ${ }^{299}$ In State v. Gaillard ${ }^{300}$ (1793), another South Carolina case, the court said that the doctrine was borrowed from civil law, and it referred extensively to Jean Domat, the seventeenth-century French civil lawyer. ${ }^{301}$ Although the court said that the doctrine had "become a part of the common law of this country, ${ }^{302}$ it did not cite a single case. ${ }^{303}$ In a North Carolina decision in 1799 , Toris $v$. Long, ${ }^{304}$ the source, as attributed by plaintiff's counsel, is Wooddeson's Lectures. ${ }^{305}$ It would thus appear that although the Virginia and Massachusetts decisions earlier in the eighteenth century evidence, some disposition to reject caveat emptor, the sound-price doctrine, if we mean by that the implication of a warranty against all defects from a sound (that is, market) price, is a creature of the late eighteenth century. And there is some reason to believe it was derived from those same English sources, Powell and Wooddeson, that tenuously evidence its existence in England, although there was some disposition to treat the doctrine as a civillaw importation. ${ }^{306}$

297 Quincy 4 (Mass. 1762).

${ }^{298} 1$ S.C.L. (1 Bay) 324, 326 (1793), discussed in text at notes 416-418 infra.

239 $1 \mathrm{~J}$. PowelL, supra note 50, at 150.

soo 2 S.C.L. (2 Bay) 11 (1793).

301 Id. at $17,18,19$.

${ }_{302}$ Id. at 17.

303 Furthermore the court did not rest its decision on a warranty implied from the price. The plat that the seller produced at the sale of the land in issue represented the property as having a good stream on it, which the purchasers needed. The court called this "fraud or misrepresentation," even though the Commissioners apparently did not know about the error. Id. at $18-19$.

30s 1 N.C. (Tay.) 17 (1799).

${ }^{305} \mathrm{Id}$. at 18.

${ }^{306}$ Other evidence cited in Horwitz, supra note 1, at 926 n.52: Rench v. Hile, 4 Har. \& McH. 495 (Md. 1766) (dealing with express warranties); Mackie's Ex'r v. Davis, 2 Va. (2 Wash.) 219 (1796) (dealing with a warranty of title, not quality), $1 \mathrm{Z}$. SwiFr, supra note 74, at 384 (although Swift cites no authority on this point, his source was probably Powell). 
Almost as soon as the sound-price doctrine was expressed, it came under attack. In English law, caveat emptor had a long history, and it is apparent from counsel's vigorous argument in Waddill $v$. Chamberlayne ${ }^{307}$ (1735) that there was always a school of thought that favored it in eighteenth-century America. As Horwitz points out, ${ }^{308}$ in Seixas v. Woods ${ }^{309}$ (1804), the New York Supreme Court rejected the sound-price doctrine in a 2-1 decision, relying on English authorities. ${ }^{310}$ Other jurisdictions soon followed: Horwitz cites cases from the period 1816-26 in Connecticut, Massachusetts, Virginia, and Pennsylvania. ${ }^{311}$ The sound-price doctrine survived only in the Carolinas. ${ }^{312}$

Abandoning the sound-price doctrine, however, did not mean adopting caveat emptor in all its rigors. With the exception of the Carolinas, the courts did not imply a general warranty against defects from the soundness of price, but under the will theory of contracts they developed a body of law on implied warranties and the effect of sales by description that very considerably reduced the significance of the doctrine of caveat emptor. Although the subject is too complex to explore here, Horwitz conveys an unbalanced picture by presenting the history of the law of sales in the early nineteenth century as predominantly concerned to adopt caveat emptor and by neglecting the whole development of implied terms protective of the buyer..$^{313}$

${ }^{307}$ Reported in 2 Virginia Colonial Decisions, supra note 296, at B45. See text at note 296 supra.

30: Horwitz, supra note 1 , at 945.

203 Cai. R. 48 (N.Y. Sup. Ct. 1804).

310 Horwitz, supra note 1 , at 945 , portrays the decisions as "relying on a doubtfully reported seventeenth century English case" (Chandelor v. Lopus, Cro. Jac. 4, 79 Eng. Rep. 3 (Exch. Ch. 1603)). In fact, this case was only one of five relied on by Thompson, J.; he also cited 1 \& 2 J. Fonblanque, Treatise of Equity (1st ed. London 1793-94) in support. Seixas v. Wood, 2 Cai. R. at 52-54. Kent, J., cited numerous cases, including Parkinson v. Lee, 2 East. 314, 102 Eng. Rep. 389 (K.B. 1802), the report of which had presumably just reached New York; he said he would prefer the civil-law rule, "if the question was res integra in our law." Id. at 55. Kent understood the common-law rule as requiring the vendor to disclose only defects known to him and which the purchaser could not be expected to learn through observation and inquiry. Id. at 54-56.

311 Horwitz, supra note 1 , at 945 n.151. But see 2 J. KeNT, Commentaries on American LAw 479 (2d ed. New York 1832) (1st ed. New York 1827) (suggesting that his own opinion in Seixas was wrong on its facts); W. STORY, supra note 58 , 1 1 $831-839$, at $710-18$ (ignoring Seixas in his discussion of the state this body of law had reached by 1847); The Doctrine of Implied Warranty on the Sale of Personal Chattels, 12 AM. JuR. 311, 326 (1834) ("the case of Seixas $v$. Woods, we believe, is now generally in practice disregarded").

312 W. STORY, supra note 95, § 832, at 710-11 \& 711 n.2.

${ }^{313}$ For a useful essay on the subject, see The Doctrine of Implied Warranty on the Sale of Personal Chattels, supra note 311. 


\section{F. Joinder of Express and Implied Contracts}

Horwitz associates his older, equitable conception of contract with the rule of pleading that permitted the joinder of counts on express and implied contracts, and the victory of the will theory of contract in the nineteenth century with the disappearance of this rule. ${ }^{314}$ In the eighteenth century, for example, in an action of indebitatus assumpsit for the price of goods sold and delivered, the liability was based on an express contract between the parties, whereas in the action for money had and received, the liability might be imposed by law in the absence of any agreement by the defendant. For Horwitz, these two actions reflected "very different conceptions of contract . . . . One was based on an express bargain between the parties; the other derived contractual obligation from . "natural justice and equity." "315 Eighteenth-century lawyers, however, did not "perceive any latent theoretical contradictions involved in joining counts on express and implied contract." 316 As a result, "the equitable tradition in the common counts"317 remained alive. It is not quite clear what Horwitz means by this phrase, but presumably he is implying that the joinder of counts allowed juries to decide in terms of equitable notions inherent in enforcing implied contracts even when there was an express agreement between the parties.

This practice supposedly changed with the collapse of the old conception of contract. "In the nineteenth century the practice of joining counts on express and implied contracts began to be viewed as contradictory, and the rule was ultimately laid down that the existence of an express agreement precludes recovery in quantum meruit." ${ }^{18}$ Horwitz supports this by a reference ${ }^{319}$ to Story's treatise on contracts in which Story maintains that " $[t]$ he general rule is, that a contract will be implied only where there is no express contract, 'expressum facit cessare tacitum.' "'320

Horwitz's account is confused in a number of ways. It is true, of course, that forms of assumpsit were used to enforce different kinds of agreements: express agreements, agreements that were implied only in the sense that they were inferred from conduct, and

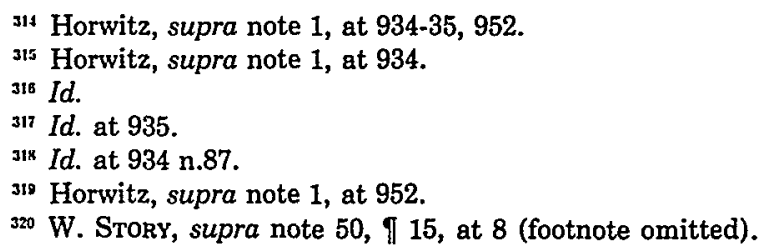


agreements that were implied in the more radical sense of being imposed by law, irrespective of actual agreement between the parties. It is also true that as a consequence there was a considerable degree of analytical confusion of categories from the seventeenth century onward..$^{321}$ But it is mistaken to say that it ever became the rule that counts on express and implied contracts could not be joined. Chitty states the rule in his day to be that "[i]n actions in form ex contractu, the plaintiff may join as many different counts as he has causes of action in assumpsit." 322 Chitty notes that while it remained usual to add a quantum meruit or valebant count to an indebitatus count, that practice had become unnecessary. ${ }^{323}$ The plaintiff could recover "under an indebitatus count . . . what may be due to him, although no specific price or sum was agreed upon." 324 Since the indebitatus count could now be used where only a quantum meruit or quantum valebant count could work before, the latter counts had become "in no case necessary." 325 Eventually, these counts passed out of use, and quantum meruit survived as a substantive doctrine, not as a form of pleading. ${ }^{326}$

That it was long a common practice to join counts does not mean that a contract would be implied when there was an express contract. The available evidence indicates that a plaintiff used to set forth different counts in the same declaration not to inflate the agreed price by declaring on quantum meruit, but to have something to fall back on "lest he should fail in the proof" 327 of his assumpsit. What Story was expounding in the passage quoted by Horwitz ${ }^{328}$ was not a pleading rule, but a substantive doctrine that was not new. It had never been suggested that claims to a quantum

s2i See A. Simpson, supra note 42 , at $489-505$ and the authorities cited therein.

$3221 \mathrm{~J}$. Chitty, A Treatise on the Parties to Actions, The Forms of Action, and on Plzading 200 (4th ed. Philadelphia 1825) (1st ed. London 1809). In addition, it was "usual, particularly in assumpsit, debt on simple contract, and action on the case, to set forth the plaintiff's cause of action in various shapes in different counts." Id. at 392-93 (footnotes omitted). See also $1 \mathrm{~W}$. ThDD, supra note 89, at 10-12.

s23 1 J. ChITTY, supra note 322 , at 394 (footnotes omitted).

324 Id. at 337. See Pynchon v. Brewster, Quincy 224 (Mass. 1766), discussed in text at notes 262-267 supra.

$3251 \mathrm{~J}$. CurTTY, supra note 322 , at 337.

328 A later edition, $1 \mathrm{~J}$. Chittry, A treatise on the Parties to Actions, and on Pleading 342 (8th ed. Springfield, Mass. 1840) states that the pleading rules of Trinity Term, 1 Will. IV virtually abolished the quantum meruit and valebant counts. See also id. at 414-18 for the rules adopted at Hillary Term, 4 Will. IV. For the early history of this development, see A. Simpson, supra note 42 , at $498-99$.

$3273 \mathrm{~W}$, BLACKSTONE, Commentaries *295. See also text at note 335 infra.

${ }^{22 s} \mathrm{~W}$. STORY, supra note $58, \uparrow 15$, at 8 , quoted in text at note 296 supra; Horwitz, supra note 1 , at $952 \&$ n.191. 
meruit-and it is with these that Horwitz is especially concerned-could be used to bypass the agreed price if there was one; insofar as Story's principle involves no more than that, it involves nothing novel.

In the nineteenth century there did develop a considerable body of relevant case law grouped around two doctrines. The first was the old doctrine that an entire contract could not be apportioned. ${ }^{328}$ Thus, if $A$ agreed to perform a piece of work for $B$, and performance was not completed, $A$ could not recover on a pro rata basis, and this rule applied quite irrespective of why the entire contract had not been performed. The leading case here for the nineteenth century is Cutter $v$. Powell ${ }^{330}$ (1795). The other doctrine, which is also found in that case, produces much the same result, but it is quite differently formulated: "Wherever there is an express contract the parties must be guided by it; and one party cannot relinquish or abide by it as it may suit his advantage." 331 Story's formulation "that a contract will be implied only when there is no express contract" 332 is a version of this second way of looking at the matter. Story does, however, later discuss the doctrine of entire contracts, ${ }^{333}$ noting its effect on the right to recover on a quantum meruit.

Whether the evolution of the law on this subject is viewed as a transformation of the older law depends upon whether there had been a time when entire contracts were apportioned, allowing pro rata recovery on partly performed contracts, or when plaintiffs could inflate the agreed price by declaring on a quantum meruit. There is no evidence that these things had ever generally been so. Indeed, it is curious that although the ancient entire-contract doctrine was relied on in Cutter $v$. Powell, ${ }^{334}$ the court there also treated as quite settled that express contracts exclude implied ones: "That where the parties have come to an express contract none can be implied has prevailed so long as to be reduced to an axiom in the law."335 So it was put by Lord Kenyon in 1795, and Horwitz has provided no evidence to refute it.

329 On the early history of this doctrine, see A. Simpson, supra note 42 , at $69-70,153,528$.

3306 T.R. 320, 101 Eng. Rep. 573 (K.B. 1795).

331 Id. at 324, 101 Eng. Rep. at 576 (Ashhurst, J.).

332 W. STORY, supra note 58 , I 15, at 8-9. Story's formulation is, as Horwitz points out, an expression of the will theory of contract. Horwitz, supra note 1, at 952.

${ }^{333} \mathrm{~W}$. SToRY, supra note 58, II 21-25, at 12-17.

336 T.R. 320, 101 Eng. Rep. 573 (K.B. 1795).

335 Id. at 324,101 Eng. Rep at 576. 


\section{The Text Writers}

To Horwitz, English and American text writers of the late eighteenth and first half of the nineteenth centuries have a special significance: they are the denouncers of older and better ways of thinking about contract law. Horwitz's opening shots are directed against the ghost of John Joseph Powell: "Beginning with the first English treatise on contract, Powell's Essay Upon the Law of Contracts and Agreements (1790), a major feature of contract writing has been its denunciation of equitable conceptions of sub'stantive justice as undermining the 'rule of law.' "' 336 Horwitz presents Powell as having been in the forefront of a new movement that adopted the will theory of contract and argued, among other new doctrines, that courts of equity should not be permitted to refuse to enforce contracts for exorbitancy of price..$^{337}$

Horwitz reads the text writers to support his thesis in significant ways. He uses them to provide evidence for the existence of some of the equitable doctrines that he believes dominated eighteenth-century courts and also for the sharp reaction against equitable conceptions that he believes took place around the turn of the century. In my view, Horwitz is wrong on both counts.

In the first place, Horwitz overlooks that many of the most influential doctrines in the texts of the time were drawn from older, Continental writers. I have argued elsewhere that in the nineteenth century contractual ideas from the civilian and natural lawyers passed into English law through text writers. ${ }^{338}$ If the argument is correct for English law, it is also correct for American law. During the critical period for Horwitz, American lawyers made extensive use of imported or specially printed editions of English law books; they also relied on English decisions to supplement the very limited indigenous materials. The first major American treatise on contract, William Story's, was published in 1844, over half a century after the English treatise by Powell. ${ }^{339}$ Before Story there was little-an unfinished series of ten articles by Theron Metcalf published in the American Jurist between 1838 and $1840^{340}$ and some coverage in

3، Horwitz, supra note 1, at 917 (footnote omitted).

337 Id. at 917-18.

333 Simpson, supra note 60.

33 W. SToRY, supra note 58.

310 Metcalf, Law of Contracts, 20 AM. JuR. 1, 249 (1838-39), 21 id. at 1, 258 (1839); 22 id. at $1,249(1839-40) ; 23$ id. at 257 (1840); 24 id. at $1,257(1840-41)$. These articles were based on lectures first delivered in 1828. They formed the basis of his important treatise, T. METCalf, Principles of the Law of Contracts (New York 1867). See Horwitz, supra note 1, at 951 n.184. 
Chancellor Kent's Commentaries ${ }^{341}(1826-28)$ were the most important. Before there were American texts, lawyers necessarily used sources, and thus law, that came from abroad.

The older Continental literature was available to Americans directly too, not only through the medium of English texts and decisions. Some of the more scholarly lawyers in a scholarly period of legal development could read Continental authors in the original. For the others, there was a steady stream of translations. Pothier, who died in 1772, was especially important. His Traité des obligations (1761-64) was published in America in two different translations in at least five editions between 1802 and $1853 .{ }^{342}$ This was a work based on much older sources; insofar as it contained modern law, it was old law worked up into a form appropriate for mid-eighteenth-century France. English translations were also available of Grotius's De Jure Belli ac Pacis (Paris 1625), ${ }^{343}$ Pufendorf's De Jure Naturae et Gentium (London 1672), ${ }^{344}$ Domat's Les lois civiles dans leur ordre naturel (Paris 1689), ${ }^{345}$ and even such a relatively minor work as Heineccius, Elementa Juris Naturae et Gentium, published at Halle in 1738, was translated into English only three years later. ${ }^{346}$ Still more Americans would have learned about the Continental tradition through the works of theological writers such as Rutherford ${ }^{347}$ and Paley. ${ }^{348}$ And there was widespread knowledge of the French Code Civil.

It is not the purpose of this article to discuss the complicated problem of why nineteenth-century England and America were receptive to these older, Continental legal doctrines. The adaptability

31 Principally in 2 J. KENT, supra note 311, Lecture 39, "Of the Contract of Sale," at 363-436 in the first edition and at 449-558 in the second.

342 R. Pothier, A Treatise on Obligations Considered in a Moral and Legal View (F. Martin trans. Newburn, N.C. 1802). There were American editions of W. Evans's translation, entitled A Treatise on the LaW of Obligations or Contracts (1st ed. London 1806), in 1826, 1839, and 1853. Several of Pothier's other works also appeared in translation in America. For a nineteenth-century American view of Pothier, see Life and Writings of Pothier, 12 AM. JUR. 341 (1834).

${ }^{313} \mathrm{H}$. Grotius, ON the LAW OF WAR AND PEACE (English translations appeared in 1654, $1655,1682,1738$, and 1814).

34 S. PUfendorf, Of the Law of Nature and Nations (English translations appeared in $1703,1710,1729$, and 1749 and an abridged version appeared in 1716).

345 J. Domat, supra note 29 (English editions appeared in 1722 and 1737).

316 J. Heineccius, Metrodical System of Universal Law (G. Turnbull trans. 1741). See the praise of Heineccius in Life and Writings of Pothier, supra note 342, at 343-44.

37 E.g., 1 \& 2 T. RUTHERFoRd, INSTTTUTES OF NATURAL LaW (1754-56).

3s E.g., W. Paley, Moral and Political PhILOSOPhy (1784). This work was enormously popular; fifteen editions appeared in Paley's lifetime (d. 1805). 
of these doctrines to the needs of an industrializing society is no doubt part of the answer. But there is an obvious difficulty in understanding the ideas of the text writers, so many of which were borrowed from an older literature, simply in terms of nineteenthcentury English or American industrial capitalism. If, for example, the rule in Hadley $v$. Baxendale ${ }^{349}$ (1854) is, as it has been argued, ${ }^{350}$ peculiarly appropriate to mid-nineteenth-century industrial capitalism, what was it doing in Orleans in the 1760's? ${ }^{351}$ But such questions do not appear in Horwitz's work on contracts.

The narrower question is whether the authors Horwitz cites mark a sharp break with eighteenth-century equitable ideas. Powell, we are told, stated that equity "'must be arbitrary and uncertain" "352 because he believed "that there could be no principles of substantive justice." ${ }^{353}$ Horwitz supports this statement with two quotations, wrenched from their contexts and 670 pages apart in Powell. ${ }^{354}$ Furthermore, he reproduces the first of these passages with two highly significant omissions, which I restore here in italics:

It is absolutely necessary for the advantage of the public at large, that the rights of the subject should, when agitated in a court of law, depend upon certain and fixed principles of law, and not upon rules and constructions of equity, which when applied there, must be arbitrary and uncertain, depending, in the extent of their application, upon the will and caprice of the judge. ${ }^{355}$

A look at the context, and at the words Horwitz omits, shows that Powell is not attacking equity in this passage, but is doing something entirely different, defending the separation of law and equity. Two pages before the passage just quoted, Powell writes that he does not object "to such temporary modifications of the law, as must and ought to be made to fit it to the exigencies of civil society." 356 It is therefore good that courts of equity can adapt remedies. But "the rights of the subject should, when agitated in a court of law, depend upon certain and fixed principles of law" because, when applied in

3s 9 Ex. 341, 156 Eng. Rep. 145 (1854).

${ }^{350}$ Danzig, Hadley v. Baxendale: $A$ Study in the Industrialization of Law, 4 J. Legal STUD. 249 (1975).

311 R. Pothier, Traite des obligations, pt. 1, ch. 2, art. $3, \S \S 159-172$, at 139-58, especially $\S 169$, at 153-54 (nouv. ed. Paris 1777) (1st ed. Paris 1761).

a 32 Horwitz, supra note 1, at 918 (quoting $1 \mathrm{~J}$. Powell, supra note 50, at $\mathrm{x}$ ).

333 Horwitz, supra note 1 , at 918.

34 See text and notes at notes 355,359 infra.

${ }^{355}$ I J. PowelL, supra note 50, at x; Horwitz, supra note 1, at 917-18.

3ss $1 \mathrm{~J}$. PowelL, supra note 50, at viii. 
a court of law, the "rules and constructions of equity must be arbitrary and uncertain." 357

Against this passage from Powell's introduction, Horwitz juxtaposes one from the second volume. I quote Horwitz quoting Powell:

A court of equity, for example, should not be permitted to refuse to enforce an agreement for simple "exorbitancy of price" because "it is the consent of parties alone, that fixes the just price of any thing, without reference to the nature of things themselves, or to their intrinsic value . . . . [T] concluded, "a man is obliged in conscience to perform a contract which he has entered into, although it be a hard one ...."The entire conceptual apparatus of modern contract doctrine . . a arose to express this will theory of contract. ${ }^{358}$

In reality, in this passage Powell is neither innovating nor advocating a modern will theory. He is reporting ${ }^{359}$ and explaining Keen $v$. Stuckely ${ }^{360}$ (1721), where, some seventy years earlier, the significance of exorbitancy of price had been raised but not decided. The extract quoted by Horwitz attempts to explain why "exorbitancy of price, uncoupled with circumstances of fraud, has not yet been determined to be a ground, -for the court of Chancery to refuse its interposition on behalf of the vendor of an estate." ${ }^{361}$ Powell's ex-

357 Id. at $\mathrm{x}$, reproduced in full in text at note 355 supra.

$3 s s$ Horwitz, supra note 1 , at 918 (quoting 2 J. Powell, supra note 50 , at 229 ). The passage is presented by Horwitz as if Powell were there giving a reason for his alleged belief that there are no principles of substantive justice, which in the context he was not.

359 I am aware that the line between "reporting" and "advocating" is often not very clear. Here, however, Powęll's explanation of why even equity had not refused, on 'grounds. of exorbitancy of price alone, to enforce contracts for the sale of an estate is closely related to arguments by counsel in the case. If such reporting is taken to mean that Powell was sympathetic with the views reported, it should be pointed out that only eight pages earlier, when discussing the grounds upon which specific performance should be refused, he states this remarkably wide principle:

Therefore, no rule is better established than, that every agreement, to merit the interposition of a court of equity in its favour, must be fair, just, reasonable, bona fide, certain, in all its parts, mutual, useful, made upon a good or valuable consideration, not merely voluntary, consistent with the general policy of a well-regulated society, and free from fraud, circumvention or surprize; or at least such agreement, must, in its effect, ultimately tend to produce a just end.

$2 \mathrm{~J}$. Powel., supra note 50, at 221 (emphasis in the original). See also note 186 supra.

${ }_{360}$ Gilb. Rep. 155, 25 Eng. Rep. 109 (H.L. 1721). The decision is also reported under the name Kien v. Stukeley, I Bro. 191; 1 Eng. Rep. 506 (H:L. 1722 [sic]).

$3612 \mathrm{~J}$. PowelL, supra note 50, at 228 (emphasis added, but later on the same page Powell repeats the clause and emphasizes the "yet": "But although exorbitancy of price has not yet been held a ground to refuse the interposition of a court of equity . . . Id. at 228-29). 
planation is very similar to what counsel had argued before the court in 1721:

On the other Side, 'twas said, that a Man was obliged in Conscience to perform a Bargain, though it was a hard one; and where he was obliged in Conscience, it was no Hardship upon him to be compelled thereto; that nothing in the World was more uncertain than the Price of Land; for Land may be worth 40 Years Purchase to one Man, that was worth but 20 to another. ${ }^{362}$

Powell's personal view, which was more benign than Horwitz reveals, is quite clearly expressed elsewhere:

And although inadequacy of price, considered abstractedly qua such, is not a ground to invalidate a contract; yet; there is a great opinion (and which I trust will not be suffered to lye dormant, when occasion offers to give effect to it) that, taken in another light, and not merely in the view that the price is inadequate, the circumstance of inadequacy alone can be made a ground for setting aside a contract. I mean, in the light of furnishing self-evident demonstration,-from the intrinsic nature and subject of the bargain itself, of fraud; evincing that the party who suffers the loss must have been imposed upon, and cannot be considered as having been in possession of an understanding adequate to render him capable of contracting; in which case no obligation could be incurred by him..$^{363}$.

This is not an isolated passage. Powell also favored a doctrine that gave the purchaser of goods for a sound price a right to avoid the contract if the goods were not sound. ${ }^{364}$ And these positions are consistent with his whole approach to contracts, which he explains in his preface-his apologia. "Contracts comprehend the whole

32 Gilb. Rep. 155, 156, 25 Eng. Rep. 109, 109 (Ch. 1721).

363 2 J. PoweLl, supra note 50, at 157-58. See also id. at 78. Powell discusses inadequacy of price in id. at 78 (Will equity refuse to enforce?), 152 (Will equity set aside?), 157-58 (Will equity set aside?). He discusses exorbitancy, id. at 228-29 (Will equity grant specific performance?). I would not place much significance upon his reference to "inadequacy" in one place and "exorbitancy" in another, or his discussing the setting aside of contracts only for inadequacy, not for exorbitancy. To be charged an exorbitant price means that one is receiving an inadequate consideration (if not, strictly speaking, an inadequate price). Thus, Powell writes, "Inadequacy of price, abstracted from all other considerations, seems of itself . . to furnish no ground on which a court can set aside, or rather relieve a party to a contract . : . . But if the cause of the inequality of price be founded in circumstances" from which the court might conclude that consent was not free, or was conditional, the contract might be set aside. Id. at 152 (emphasis in the original). Here, at least, Powell treats "inadequacy of price" and "inequality of price" as synonymous.

ss 1 id. at 150 , discussed in text at note 283 supra. 
business of human negotiations." ${ }^{365}$ In spite of the different objects of contracts, however, "the contracts respecting them must uniformly be determined by the principles of natural or civil equity." 366 So Powell's aim was to analyze the authorities and thereby to "discover the general rules and principles of natural and civil equity on which those decisions are founded." "367 These are hardly the sentiments of the Powell whom Horwitz presents as denying the existence of principles of substantive justice and as claiming that equity must be arbitrary and uncertain.

What Powell is said to have begun, Joseph Story is said to have completed. Horwitz presents Story's Equity Jurisprudence, ${ }^{368}$ published in 1835-36, as the final step in the process that brought about the denunciation of "equitable conceptions of substantive justice as undermining the 'rule of law." "368 In Story, Horwitz writes, "American law finally yielded up the ancient notion that the substantive value of an exchange could provide an appropriate measure of the justice of a transaction." ${ }^{370}$ But Story is an unfortunate choice, for in fact he states as law in 1836 what Powell, far from attacking, had hoped would become law. ${ }^{371}$ Story acknowledges that "[i]nadequacy of consideration is not then, of itself, a distinct principle of relief in Equity." 372 He goes on to say, however, that "there may be such an unconscionableness or inadequacy in a bargain, as to demonstrate some gross imposition or undue influence; and in such cases Courts of Equity ought to interfere, upon the satisfactory ground of fraud." 373 The same doctrine is, incidentally,

${ }^{365} 1 \mathrm{~J}$. PowgLt, supra note 50, at iii.

sob Id.

387 Id. at iv.

368 I \& 2 J. STORY, CoMmentaries on EquTTY JURISPRUdENCE As ADMMNISTEREd IN ENGLAND AND AMERICA (Boston 1835-36).

369 Horwitz, supra note 1 , at $917,950-51$. None of the writers mentioned talks about "the rule of law;" the expression is Horwitz's.

${ }^{370}$ Id. at 950. The precise meaning of "ancient notion" is somewhat obscure, as is its supposed antiquity; no proposition phrased in a remotely similar manner is, so far as I am aware, to be found in any law report or text in the history of English law. It can only be understood as referring to some doctrine regarding inadequacy of price as vitiating contracts.

${ }^{371}$ See text at note 363 supra.

$3721 \mathrm{~J}$. STORY, supra note 368 , If 245 , at 249.

373 Id. T 246, at 250 (footnote omitted). Story continues:

But then such unconscionableness or such inadequacy should be made out, as would, to use an expressive phrase, shock the conscience, and amount in itself to conclusive and decisive evidence of fraud. And where there are other ingredients in the case of a suspicious nature, or peculiar relations between the parties, gross inadequacy of price must necessarily furnish the most vehement presumption of fraud.

Id. (footnotes omitted). See generally id. ๆf 244-250, at 248-54. The "expressive phrase" is 
stated in England by Chitty in $1826^{374}$ in a slightly weaker form; William Story follows Joseph. ${ }^{375}$ Later in the century, in 1858, Fry's classic $A$ Treatise on the Specific Performance of Contracts ${ }^{376}$ has essentially the same doctrine in a slightly stronger form. ${ }^{377}$ Nothing dramatic seems to have occurred. ${ }^{378}$

Between Powell and Joseph Story, Horwitz relies primarily on three writers, Daniel Chipman, ${ }^{379}$ Nathan Dane, ${ }^{380}$ and Gulian Verplanck. ${ }^{381}$ So far as Chipman is concerned, the passages cited ${ }^{382}$ have a peculiar context that is not in the least concerned with the invalidity or modification of contracts on the ground of unfairness of price. Chipman nowhere discusses this topic in his strange book. The book is wholly concerned with legal problems arising in an agricultural economy in which, although trade is conducted by reference to prices expressed in the normal way in money terms, because of the lack of specie debts are commonly settled by converting the price into the form of goods. ${ }^{383}$

from Eldon in Coles v. Trecothick, 9 Ves. Jun. 234, 246, 32 Eng. Rep. 592, 597 (Ch. 1804), discussed in text at notes 204-205 supra. See also text at notes 177-180, 203-210 supra.

374 J. ChITTy, supra note 58 , at 224.

375 W. STORY, supra note 58, \ 432 , at $354-55$, I 483 , at 402 .

${ }^{376}$ E. FRY, supra note 208.

377 Id. at 127-32.

${ }^{378}$ One explanation for the repeated insistence that inadequacy as such does not invalidate a contract may be a reluctance to formulate a doctrine of equity in terms expressly contradictory of an established and unquestioned common-law rule, that inadequacy of consideration is irrelevant.

370 D. Chipman, An Essay on the Law of Contracts, for the Payment of Specifick Articles (Middlebury 1822), discussed in Horwitz, supra note 1, at 947.

sso 1-9 N. Dane, A General Abridgement and Digest of American Law (Boston 1823-29), discussed in Horwitz, supra note 1, at 947, 949-51.

${ }^{381}$ G. VERPLANCK, supra note 44, discussed in Horwitz, supra note 1, at 946-49. Horwitz also includes Metcalf, supra note 340 , but if I understand his argument, it is merely that Metcalf marginally belonged to the new movement because he was "beginning to pretend that contractual obligation derives only from the will of the parties," Horwitz, supra note 1, at 952; predominantly he belonged to the old order. Id. at 951-52. No passage is cited to support this claim; all we are given is a passage which shows quite clearly that Metcalf did not think that all contractual obligations arose from the will of the parties. Id. at 952. This makes it difficult to discuss the claim.

3x2 Horwitz, supra note 1, at 947 (citing D. ChIPMAN, supra note 379, at 109-11). In a footnote, Horwitz states that Chipman is the first American legal writer to use the notion that tender can in appropriate circumstances be treated as equivalent to performance. Id. at 930 n.68. If this is taken to suggest that the idea was unknown or little known in American before 1822 , it is incorrect; the idea is commonplace in the standard books available. Of course, since Chipman's was the very first American book specifically on contract, though it is not a general treatise on the subject, it can be said to contain the first discussion of tender in an American text or treatise on contract.

. ${ }^{x} \mathrm{~T}$ Horwitz states that Chipman was arguing that "[o]nly the market could establish a fair basis for exchange," when he criticized a particular Vermont custom. Horwitz, supra note 1 , at 947. This is most misleading. Chipman discusses a custom operating in Vermont, "to 
Horwitz also divorces Nathan Dane's views from their context in an unhelpful way. The discussion of law and morality from which Horwitz quotes is in fact taken from a section of Dane's Abridgement ${ }^{384}$ that discusses the laws of Rome and the civilian system in France: ${ }^{385}$ the topic under discussion is the doctrine of laesio enormis, ${ }^{386}$ according to which a sale of immovable property could be set aside if the price was less than half the value. Dane's discussion of inadequacy of price in American law is to be found elsewhere ${ }^{387}$ Horwitz states that Dane attacked "all conceptions of a substantive theory of exchange." 388 One of the passages Horwitz quotes in support ${ }^{389}$ indeed evinces great hostility to English decisions ("trash," "the productions of inferior lawyers"), but the point Dane is making has absolutely nothing to do with inadequacy of price or fair exchanges. He is talking about post-1776 English decisions on property, not contract: he actually commends eighteenthcentury equity as it existed in England before the American Revolution. ${ }^{390}$

It is apparent that Verplanck's Essay on the Doctrine of Contracts $^{391}$ (1825) presents Horwitz with a problem. Verplanck's

have grain apprised, as well as cattle or horses, when tendered in payment of debts," not at market price, but at "a certain common price considerably above the cash price." $D$. Chipman, supra note 379, at 109. I take this to refer to an understood equivalence between money and grain, cattle or horses-for example, wheat might be treated on the books as worth a dollar a bushel although when it did change hands for hard specie it was for less. The point of this custom may have been to protect the farmer-debtor against a sharp decline in the price of agricultural commodities when his debt was due. Chipman, however, interprets the custom as an ineffective attempt to keep agricultural prices high, and he attacks it on various grounds. When he says "let money be the sole standard in making all contracts," $i d$. at 111, quoted in Horwitz, supra note 1, at 947 , he means by "money," in this context, real cash prices, as opposed to notional prices that involve treating corn as a form of money and not just a substitute for it. Chipman is not discussing whether, in general, only a competitive market can establish a fair basis for exchange.

ss I N. DANE, supra note 380, at 100-01. Horwitz, supra note 1, at 949-50.

sss Dane there describes sections 3 to 27 as follows: "Thus far, 3 to 27 , both included, is extracted from the law of Rome and France." 1 N. DANE, supra note 380, at 101.

384 See text at notes 28-29 supra.

$3971 \mathrm{~N}$, DANE, supra note 380 , at $89,108-10,661$.

sss Horwitz, supra note 1, at 950.

389 Id. (quoting $1 \mathrm{~N}$. DANE, supra note 380 , at 107-08).

$3001 \mathrm{~N}$. DANE, supra note 380, at 107. Horwitz's use of this source is not improved by his juxtaposing another passage from Dane, which is indeed about inadequacy of price, but which occurs over 500 pages later, and which he quotes without any of the qualifications in the original. Horwitz, supra note 1, at 950, n.177 (quoting 1 N. DANE, supra note 380 , at 661). Dane's point is in fact that inadequacy may be evidence of fraud. See text at notes 205-234 supra.

39 G. Verplanck, supra note 44. On Verplanck, see R. July, The Essential NEw Yorker: Jultan Crommelin Verplanck (1951). At the time the book was written, Verplanck had no reputation as a lawyer although much later, between 1838 and 1841 , he achieved great distinction when he became the dominant figure in the New York Court of Errors. Unhappily, he never sat on a case that enabled him to consider judicially the views expressed in his Essay on the law of sale. 
argument was provoked by the decision of the Supreme Court in Laidlaw v. Organ ${ }^{392}$ (1817) and consists of a sustained attack on the doctrine of caveat emptor. ${ }^{393}$ Unlike Horwitz, who seems to think that caveat emptor was an innovation of the late eighteenth or early nineteenth century, ${ }^{394}$ Verplanck thought it was the ancient rule "of Fitzherbert and Croke." ${ }^{395}$ But this was to him no recommendation, and he believed it should be extirpated from the law. ${ }^{386}$ Verplanck's hostility to caveat emptor would seem at first sight to place him on the side of the angels. But he regarded the notion of inadequacy of price as incoherent and argued that the law should not consider inadequacy of price by itself as a ground for contractual invalidity. ${ }^{307}$

Verplanck was trying to destroy the principle of caveat emptor and lay the basis for a more moral law of sales without undermining the market as a setter of price. He did this essentially by distinguishing between contracts for the sale of unique goods (such as a racehorse or a Rembrandt, for which value depends only on the subjective desires of the parties) ${ }^{398}$ or speculative contracts (in which everyone's cards are, so to speak, known to be hidden), and, on the other hand, contracts for goods for which there is a going market price. ${ }^{399}$ In the latter case, dealers "of ordinary prudence" take into account those facts that affect the market price. ${ }^{400}$ Where the going price is asked and paid, therefore, it may be presumed that both parties implicitly made the existence of the "common facts" that affect market price a condition of the contract ${ }^{401}$ and that one party does not have, or is not taking advantage of, superior knowledge

31215 U.S. (2 Wheat.) 178 (1817). See G. VerplancK, supra note 44, at 4-5.

393 Verplanck called caveat emptor "an odious maxim" which should, "with all its trains of absurdities and contradictions . . . be for ever expelled from our courts." G. Verplanck, supra note 44 , at 217 .

3n4 Horwitz, supra note 1, at 945.

3 G. VERPLANCK, supra note 44 , at 29 . Verplanck thought that some inroads on the doctrine had been made, beginning around 1750 , with the evolution of a rule to the effect that there was an implied warranty of quality when a fair price had been given (the sound-price doctrine). Id. at 28-29, 29 n.* (citing $2 \mathrm{R}$. Wooddeson, supra note 238, at 415). He states that "Professor Wooddeson does not cite any judicial decisions in aid of his own opinion, but it seems to have been often so ruled at Nisi Prius, in his day." G. VERPLANcK, supra note 44, at 29 n.*. Verplanck thought that the new rule had then been rejected in a series of decisions beginning with Stuart v. Wilkins, 1 Dougl. 18, 99 Eng. Rep. 15 (K.B. 1778), and that Parkinson v. Lee, 2 East. 314, 102 Eng. Rep. 389 (K.B. 1802) finally restored the rule "as it stood in the days of Fitzherbert and Croke." See text at notes 289-295 supra.

"G. VERPLANCK, supra note 44, at 217.

$\$ 2$ Id. at $115-16,225$.

3ss Id. at 108-10, 113-15.

3 Id. at 110-13, 115-16.

${ }^{100}$ Id. at 112 .

sot Id. at 112-13 
with respect to these facts. ${ }^{402}$ From this Verplanck derived a duty of disclosure of all facts known to one party but not patent to the other if these facts, were they generally known, would affect the price of the good. ${ }^{403}$ The remaining problem concerned allocating risk of latent defects (or of other facts that would affect the price if generally known) about which both the seller and the buyer were ignorant at the time of the contract. Although Verplanck saw this as a difficult problem, ultimately, in the case of goods for which there was an ordinary market and which were sold at the market price, he thought the seller should be presumed to have assumed the risk-though his presumption was rebuttable. Where both parties were innocent, he believed consequential damages should lie where they fall. ${ }^{404}$

Verplanck does not fit into Horwitz's scheme. According to Horwitz, "the importance of [the acceptance by late eighteenth- or early nineteenth-century courts of] caveat emptor lies in its overthrow of both the sound price doctrine and the latter's underlying conception of objective value." ${ }_{405}$ Verplanck, however, rejects not only caveat emptor but (subject to important qualifications) the sound-price doctrine and "the underlying conception of objective value." ${ }^{406}$ Instead of accepting that Verplanck's complex argument does not enable the book to be categorized neatly into his analysis, Horwitz falls back upon the notion of "deeper levels." Thus, he argues that "at its deepest level, Verplanck's Essay marks the triumph of a subjective theory of value in a market economy." 407 To support this interpretation, Horwitz is forced to present Verplanck without many of the qualifications and conflicts in the Essay. Thus we are told that Verplanck thought that "value is solely determined by the clash of subjective desire." 408 Verplanck never makes this claim, and it is strictly true only for his analysis of the price of unique goods and perhaps of speculative contracts. His analysis of the price of goods for which there is a regular market, as we have seen, is more reminiscent of the communis aestimatio of Christian moralists than of a subjectivist and individualist will theory of contract. ${ }^{409}$

102 Id. at $120,125-26$.

103 Id. at 125-26, 227-28.

so Id. at 141-52, 229-30.

${ }^{105}$ Horwitz, supra note 1 , at 946 n.15.

${ }^{106}$ G. VerplaNCK, supra note 44 , at $89-93$ (rejecting the just price doctrine). See note 44 supra.

${ }^{107}$ Horwitz, supra note 1 , at 948.

${ }^{108}$ Id. at 949 (citing G. VeRpLANCK, supra note 44 , at 225).

${ }^{409}$ Compare text at notes 399-404, supra with text at notes $24-26$ supra. The similarity 
Horwitz also distorts the argument of the Essay by giving no account of Verplanck's "code" of proper commercial conduct ${ }^{410}$ and by making the following disparaging remark: "Thus, while he refused in theory to separate law and morality, Verplanck confined fraud to a range sufficiently narrow to permit the contract system to reinforce existing social and economic inequalities."'11 In truth, had Verplanck's scheme been adopted, it would have produced a law of sale of dramatically higher morality than any to be found earlier or later in the history of the common law.

Actually, Horwitz need not have been troubled by Verplanck (or Chipman for that matter) for, fascinating and interesting though the Essay is, there is no reason whatsoever to suppose that it had any influence on the evolution of law in our period. At the time, Verplanck had no reputation as a lawyer, and the Essay was received with hostility or indifference. ${ }^{412}$ It would be more relevant to consider the text writers whose books were bought and used, and if this is done there is little evidence of the sustained denunciation of any "equitable doctrine." In Chitty's 1826 treatise, for example, a work of 346 pages, inadequacy of consideration receives one passage of ten lines and another of thirteen, written in a style that is hardly denunciatory. ${ }^{413}$ William Story (1847 edition) contains 1034 numbered paragraphs; inadequacy of consideration is mentioned in only five, as best I can find.114 The whole subject, though of some importance, did not appear to contemporaries to be of major importance. The law on the subject was fairly well settled and rarely invoked.

between Verplanck and the Christian moralists should not be exaggerated. Verplanck attacks the doctrine of the just price because it is based on the notion that every honest sale proceeds on the assumption of an exchange of equivalents, whereas he stresses that both parties agree to an exchange because they value what they received higher than what they give. Id. at 90. The conception of contract that he criticizes here was standard form in the Christian moralists and their successors.

"10 G. VERPLANCK, supra note 44, at 224-34.

III Horwitz, supra note 1, at 949.

$\$ 12$ R. JULY, supra note 391, at 209-11.

"13 J. CHITTY, supra note 58, at 224.

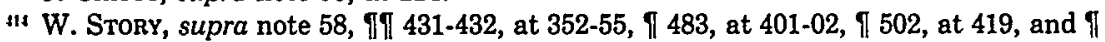
778 , at $671-72$ (I have not seen any other edition). All these paragraphs deal with the possibility of setting aside contracts for inadequacy. Circumstances that allow a court to set aside a contract would allow it to refuse specific performance, but the reverse is not necessarily the case; Story never discusses inadequacy as a ground for refusing specific performance alone.

The problem of adequacy of consideration must be distinguished from other issues involving consideration, such as its sufficiency, which Story discusses id. 1427 , at 349-50. On the distinction between adequacy and sufficiency, see text at notes 275-277 supra. 


\section{Conclusion}

When Horwitz's general account of the dramatic transformation of contract law is broken down into specific propositions, and these are then examined in detail and referred to the evidence, his thesis is found to be oversimplified. Through an unsatisfactory and loose use of evidence, he has made a complex, confused story fall into a preordained pattern. What is still more fundamental, Horwitz appears to me to have made two very dubious assumptions.

The first concerns the interpretation of the growth in scale and elaboration of contract law in the nineteenth century. Essentially, Horwitz views this as a change from one body of substantive law to another, the earlier law favoring the commercial class less than the new. Horwitz is aware, however ${ }^{415}$ that the development of contract law considerably reduced the sovereignty of the jury, whose earlier discretionary power came to be restricted by the newly elaborated law and by the extension of control over the remaining area of discretion. To sustain his pessimistic interpretation, Horwitz is forced into a romanticized view of the eighteenth-century jury, and into attributing to it a consistent and morally appealing doctrinal position. This interpretation is not supported by evidence. Because he believes that a change in substantive doctrine must have taken place, Horwitz fails to grasp the nature of the historical problem: what needs to be explained is this progressive dethronement of the jury, which is accompanied by the generation or reception of law in order not so much to replace or transform older doctrine as to provide law where before there was little or none.

Horwitz's second assumption concerns the relationship between the doctrines he discusses and the exploitation of the poor and weak. Nobody, of course, would doubt the existence of such exploitation in this period, and there is nothing in any way implausible in the claim that certain legal doctrines may facilitate such exploitation. Great care is required, however, in establishing natural links between particular doctrines and human oppression. The sound-price doctrine, for instance, admirable though it may be in some contexts, is not so admirable in others. In the Carolinas, where the doctrine flourished, it turns up in the context of sales of slaves. In the case of Timrod $v$. Shoolbred ${ }^{416}$ (1793), assumpsit was brought "for the value of a family of negroes sold at public auction, viz. a fellow called Stepney, a ploughman, his wife, a young wench, their

${ }^{415}$ Horwitz, supra note 1, at 925-26.

«16 1 S.C.L. (1 Bay) 324 (1793). 
daughter and her child, bid off at 170 .." $^{117}$ The day after he was purchased, Stepney broke out with smallpox, from which he died. The purchaser refused to pay unless the price was reduced pro rata, and the court agreed, applying the equitable doctrine and reducing the sale price. The court said: "In every contract every imaginable fairness ought to be observed, especially in the sale of negroes, which are a valuable species of property in this country." 418

In England the implied warranty arose in the context of the sale of horses. The poor did not buy horses; they walked. The doctrine of laesio enormis in the civil law protected landowners; in England the case law in chancery on sales at low value and on "catching bargains" with expectant heirs appears to have largely performed the same function. No doubt certain aspects of contract law pressed on the poor-imprisonment for debt is surely the principal villain here. But in the main, I doubt if their lot was much improved by the existence of an implied warranty of quality on the sale of victuals, or made worse by some detail of the rules for the assessment of damages. It was their misfortune to be outside the world in which such luxuries as legal actions at common law or bills in equity much mattered.

II7 Id.

"18 Id. at 325 . Hence, the court continued, the implied warranty "of soundness of the thing [sic] sold." Id. at 326. 